\title{
Metatranscriptomic analysis of small RNAs present in soybean deep sequencing libraries
}

Lorrayne Gomes Molina ${ }^{1,2}$, Guilherme Cordenonsi da Fonseca ${ }^{1}$, Guilherme Loss de Morais ${ }^{1}$, Luiz Felipe Valter de Oliveira ${ }^{1,2}$, Joseane Biso de Carvalho ${ }^{1}$, Franceli Rodrigues Kulcheski ${ }^{1}$ and Rogerio Margis ${ }^{1,2,3}$

${ }^{1}$ Centro de Biotecnologia e PPGBCM, Laboratório de Genomas e Populações de Plantas, Universidade Federal do Rio Grande do Sul, Porto Alegre, RS, Brazil.

${ }^{2}$ Programa de Pós-Graduação em Genética e Biologia Molecular, Universidade Federal do Rio Grande do Sul, Porto Alegre, RS, Brazil.

${ }^{3}$ Departamento de Biofísica, Universidade Federal do Rio Grande do Sul, Porto Alegre, RS, Brazil.

\begin{abstract}
A large number of small RNAs unrelated to the soybean genome were identified after deep sequencing of soybean small RNA libraries. A metatranscriptomic analysis was carried out to identify the origin of these sequences. Comparative analyses of small interference RNAs (siRNAs) present in samples collected in open areas corresponding to soybean field plantations and samples from soybean cultivated in greenhouses under a controlled environment were made. Different pathogenic, symbiotic and free-living organisms were identified from samples of both growth systems. They included viruses, bacteria and different groups of fungi. This approach can be useful not only to identify potentially unknown pathogens and pests, but also to understand the relations that soybean plants establish with microorganisms that may affect, directly or indirectly, plant health and crop production.
\end{abstract}

Key words: next generation sequencing, small RNA, siRNA, molecular markers.

\section{Introduction}

Until recently, analysis of the microbial diversity in environmental samples was conducted only after isolation, culture and identification of microorganisms and subsequent sequencing of cloned libraries (Cardenas and Tiedje, 2008). However, these conventional methods are limited to the minority of species that can be cultured (Chistoserdova, 2010). New culture-independent methods, such as metagenomics and metatranscriptomics, have been developed (Xu, 2006; Cardenas and Tiedje, 2008; Adams et al., 2009; Warnecke and Hess, 2009; Chistoserdova, 2010). These methods refer to studies of the collective set of genomes and transcriptomes of mixed microbial communities and may be applied to the exploration of all microorganisms that reside in marine environments, soils, human and animal clinical samples, sludge, polluted environment, and plants (Kent et al., 2007; Zoetendal et al., 2008; Adams et al., 2009; Al Rwahnih et al., 2009; Poretsky et al., 2009;

Send correspondence to Rogerio Margis. Centro de Biotecnologia e PPGBCM, Laboratório de Genomas e Populações de Plantas, Prédio 43431, Universidade Federal do Rio Grande do Sul, Caixa Postal 15005, 91501-970 Porto Alegre, RS, Brazil. E-mail: rogerio.margis@ufrgs.br.
Shi et al., 2009; Desai et al., 2010; Gifford et al., 2010; Roossinck et al., 2010). The metagenomic approaches, including metatranscriptomics, involve the sequencing of random DNA or RNA-derived complementary DNA (cDNA) profiles and subsequent determination of taxonomic diversity and prospective genes related to response to environmental conditions (Rosen et al., 2009). With the advent of new sequencing technologies (high-throughput sequencing), more data can be generated in a relatively short time, in a practical and cost-effective way (Creer $e t$ al., 2010). Moreover, this approach allows the direct sequencing of DNA or cDNA, avoiding any cloning bias and leading to large-scale studies (Adams et al., 2009).

Metagenomic analysis of RNA deep-sequencing data has been used in plant disease diagnostics, such as in grapevine (Al Rwahnih et al., 2009; Coetzee et al., 2010), sweet potato (Kreuze et al., 2009), tomato and Liatris spicata (Adams et al., 2009). Coupling of metagenomics with pyrosequencing in these studies has also allowed the detection of bacterial and fungal RNA, suggesting that this approach can contribute to massive identification of cropassociated microbiota, including pathogenic, symbiotic, and free-living organisms. 
In addition to other sequencing methodologies, deep sequencing libraries of small RNA (sRNA) can contribute to microbial identification studies as they may include non-coding RNAs (e.g. rRNA), small regulatory RNAs, such as microbial sRNAs (Shi et al., 2009) and host small interfering RNAs (Kreuze et al., 2009), as well as mRNA fragments that normally would not be represented in libraries enriched for polyA-tailed mRNA commonly used in metatranscriptomic studies. As an example of the application of high-throughput sequencing of plant sRNAs, Kreuze et al. (2009), using short read sequences of approximately 24 base pairs (bp), successfully identified viruses infecting sweet potato, even those present in extremely low titer symptomless infections.

With this in mind, the current study describes the use of high-throughput sequencing of sRNAs to identify potential pathogens and other microorganisms from samples of soybeans grown in the field and in controlled-environment conditions.

\section{Material and Methods}

\section{Plant material}

The sRNA sequences analyzed in this study were obtained from deep-sequencing libraries from different projects related to the soybean transcriptome (Genosoja and Genoprot). The libraries were constructed from root samples of soybean cultivars grown under greenhouse conditions, and from flower, seed and pod samples from soybean plants grown under field conditions.

Root samples were obtained from 'Embrapa 48' and 'BR 16' soybean cultivars grown in a greenhouse at Embrapa-Soja in Londrina, Brazil. Plants were cultivated using a hydroponic system composed of plastic containers (30 liters) and an aerated $6.6 \mathrm{pH}$-balanced nutrient solution. Seeds were pre-germinated on moist filter paper in the dark at $25{ }^{\circ} \mathrm{C} \pm 1{ }^{\circ} \mathrm{C}$ and $65 \% \pm 5 \% \mathrm{rhr}$. Plantlets were then placed in polystyrene supports with the roots of the seedlings completely immersed in the nutrient solution. Each tray containing the seedlings was maintained in a greenhouse at $25{ }^{\circ} \mathrm{C} \pm 2{ }^{\circ} \mathrm{C}$ and $60 \% \pm 5 \%$ rh under natural daylight (photosynthetic photon flux density $(\mathrm{PPFD})=1.5 \mathrm{x}$ $10^{3} \mu$ moles $\mathrm{m}^{-2} \mathrm{~s}^{-1}$, equivalent to $8.93 \times 10^{4} \mathrm{lux}$ ) and a 12:12 $\mathrm{h}$ photoperiod. Roots of seedlings with the first trifoliate leaf fully developed (V2 developmental stage) were frozen in liquid nitrogen and stored at $-80^{\circ} \mathrm{C}$ until RNA extraction.

Three stages of seed germination, pods, and mature seeds from the soybean cultivar 'Conquista' were also used in RNA extraction. In a growth chamber, seeds were incubated for 3, 5 and 7 days on rolls of moistened filter paper at $26{ }^{\circ} \mathrm{C}$. Pods (R3-R5) were collected from field plants grown at the Federal University of Rio Grande do Sul (UFRGS), Porto Alegre, Brazil.
Flower samples (R2-R3) were collected from the soybean cultivar 'Urano' grown at the experimental field of the University of Passo Fundo (UPF), in Passo Fundo, Brazil. Collected flowers were immediately powdered in Trizol (Invitrogen, CA, USA) and stored until RNA extraction.

\section{RNA extraction and sequencing}

Total RNA was isolated from roots, seeds, seedlings, pods and flowers using Trizol (Invitrogen, CA, USA), and following the manufacturer's instructions. RNA quality was evaluated by electrophoresis in $1.0 \%$ agarose gels, and the amount checked using a Quibit fluorometer and QuantiT RNA assay kit (Invitrogen, CA, USA) according to the manufacturer's instructions. Approximately $10 \mu \mathrm{g}$ of total RNA were sent to Fasteris Life Sciences SA (Plan-lesOuates, Switzerland) for processing and sequencing using Solexa technology on an Illumina Genome Analyzer GAII. Briefly, the processing by Illumina consisted of the following successive steps: acrylamide gel purification of RNA bands corresponding to the size range 20-30 nucleotides (nt), ligation of 3' and 5' adapters to the RNA in two separate subsequent steps, each followed by acrylamide gel purification, cDNA synthesis, and a final step of PCR amplification to generate a DNA colony template library for Illumina sequencing. After removing vector sequences, reads of 19 to $24 \mathrm{nt}$ were used for further analysis.

\section{Sequence analysis}

The detailed analysis of endogenous sRNAs, including microRNAs, obtained from the soybean libraries described above is the topic of a separate study and will not be discussed here. However, since in addition a large number of sRNAs unrelated to the soybean genome were identified, a metagenomic analysis was indicated to identify the origin of these sequences. To this end, all reads were assembled into contigs using the Velvet 0.7.31 de novo assembly algorithm (Zerbino and Birney, 2008) with the following parameters: hash length of 23 , coverage cut-off of 50 , expected coverage of 1,000 , and a minimum scaffold length of 100 .

Assembled contigs matching the soybean genome were eliminated from further analysis using BLAST (BLASTn) "stand alone" version 2.2.20 against the soybean genome database available at Phytozome with the following parameters: expectation value $(-\mathrm{e})$ of $1 \mathrm{e}^{-10}$, cost to open a gap (-G) of -6 , cost to extend a gap (-E) of -6 , penalty for a nucleotide mismatch (-q) of -5 . The remaining contigs were used to search the NCBI database using BLASTn (nucleotide blast) with default parameters and an expectation value of $10^{-5}$. The contigs were classified according to the sequence with the highest hit score found with BLASTn. The number of reads aligning to the contigs, coverage and average depth were determined with the SOAP tool ( $\mathrm{Li}$ et al., 2009). Default parameters were used and only filtered 
data (reads aligning to the references with a high confidence) are reported.

\section{Results}

\section{Sequence analysis}

The sRNA libraries analyzed in this study contained $5,627,802$ reads (each consisting of 19-24 bp) from root, $8,610,347$ from seeds and pods, and 9,314,206 from flower (Figure 1). The sRNA sequences were assembled into contigs ranging from 40 to 300 nucleotides, approximately. Sequence assembly produced 2,646, 15,521 and 28,382 contigs from root, seed and pod, and flower, respectively. After elimination of the soybean sequences, 253 (root), 2,574 (flower) and 1,959 (seed and pod) contigs remained for further analysis. These contigs were used in BLASTn searches against the NCBI database.

After BLASTn annotation, a large number of sequences remained unidentified (Figure 1), accounting for $73.4 \%$ of the field samples (Figure $2 \mathrm{~A}$ ) and $37.2 \%$ of the controlled environmental samples (Figure 3A). Contigs that corresponded to soybean sequences, but could not be filtered by the local BLASTn, represented $17.4 \%$ of the total contigs from field samples (Figure 2A) and 5.1\% from controlled environment samples (Figure 3A). There were also contigs corresponding to sequences from other plant species deposited in NCBI (Figures 2A and 3A).

Apart from the contigs mentioned above, 134 contigs from the controlled environment (root) and 335 from the field (flower, seed and pod) had hits to previously sequenced microorganisms and viruses (Figure 1) and provided the results shown in the following topics. These contigs were distributed in different taxonomic groups based on their best BLASTn hits (Figures 2B and 3B). Contigs showing similarities to sequences from different

Controlled envirenment

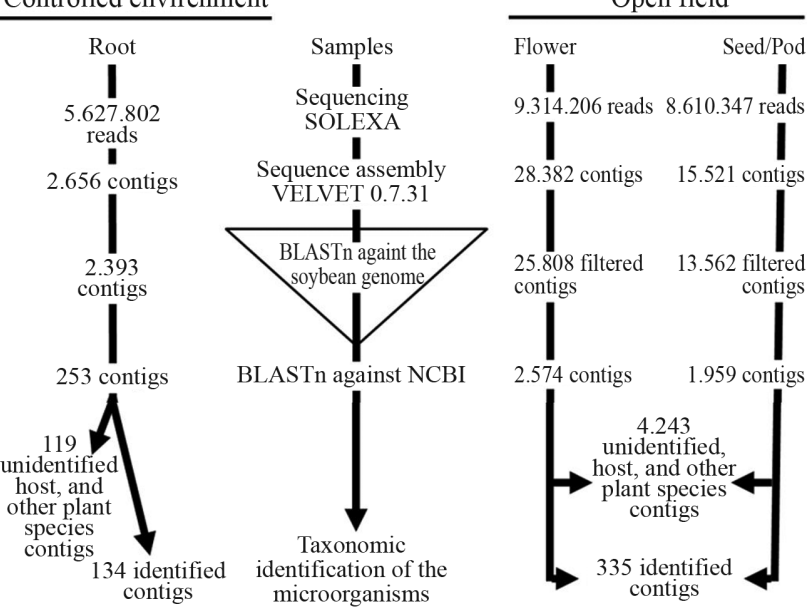

Figure 1 - Chart flow of sequence analysis. The central column identifies the methods. The number of reads obtained at each step is indicated for samples obtained from a controlled environment (left) and from field samples (right)
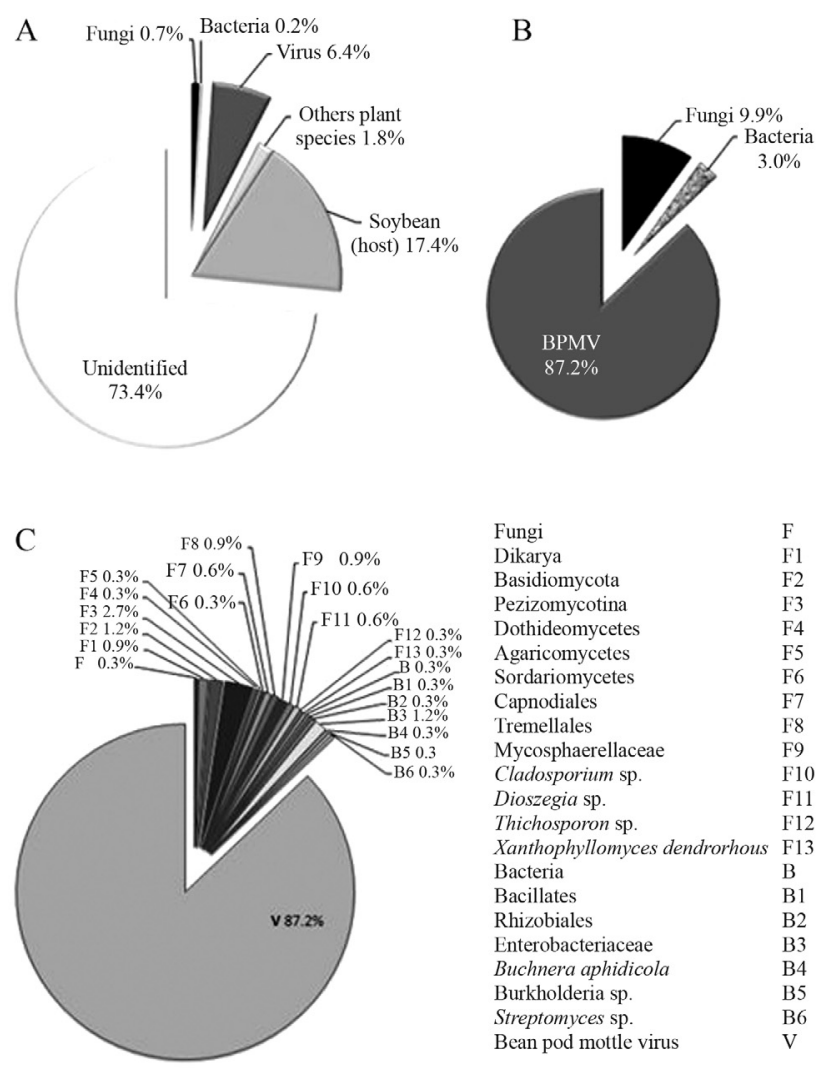

$\begin{array}{ll}\text { Fungi } & \text { F } \\ \text { Dikarya } & \text { F1 } \\ \text { Basidiomycota } & \text { F2 } \\ \text { Pezizomycotina } & \text { F3 } \\ \text { Dothideomycetes } & \text { F4 } \\ \text { Agaricomycetes } & \text { F5 } \\ \text { Sordariomycetes } & \text { F6 } \\ \text { Capnodiales } & \text { F7 } \\ \text { Tremellales } & \text { F8 } \\ \text { Mycosphaerellaceae } & \text { F9 } \\ \text { Cladosporium sp. } & \text { F10 } \\ \text { Dioszegia sp. } & \text { F11 } \\ \text { Thichosporon sp. } & \text { F12 } \\ \text { Xanthophyllomyces dendrorhous } & \text { F13 } \\ \text { Bacteria } & \text { B } \\ \text { Bacillates } & \text { B1 } \\ \text { Rhizobiales } & \text { B2 } \\ \text { Enterobacteriaceae } & \text { B3 } \\ \text { Buchnera aphidicola } & \text { B4 } \\ \text { Burkholderia sp. } & \text { B5 } \\ \text { Streptomyces sp. } & \text { B6 } \\ \text { Bean pod mottle virus } & \text { V }\end{array}$

Figure 2 - Comparative percentages of the contigs assembled from sRNA (19-24 nt) libraries of the field (crop soybean) for each sequence classification according to best hit with BLASTn. (A) All groups of organisms, (B) all groups excluding unidentified and plants and (C) best identified taxonomic groups. Bean Pod Mottle Virus (BPMV).

taxonomic groups (multiple affiliations) were classified at the taxonomic level immediately above.

\section{Taxonomic origin of sRNAs from controlled environmental samples}

The most represented taxon in the controlled environment samples belongs to the domain Eukaryota (49.3\%), including unicellular eukaryotes $(46.3 \%)$ and fungi $(3.0 \%)$, followed by the domain Bacteria (32.8\%). In addition, $17.9 \%$ of the microbial contigs could only be classified to the taxonomic level of the domain Eukaryota (Figure 3B).

Unicellular eukaryote organisms were found only in controlled environment samples. The amoeba genus Naegleria was well represented (12 contigs) within the kingdom Excavata, with one contig classified to species level, viz. Naegleria fowleri (Table 1, Figures 3C and 4C). Contigs corresponding to the phylum Kinetoplastida were distributed at different levels of taxonomic classification through the family Bodonidae, including Neobodo designis and Rhynchomonas nasuta. The family Trypanosomatidae was also identified within this phylum, including the genus Trypanosoma. Within the kingdom Chromalveolata (group Heterokontophyta), the class Chrysophyceae was identi- 
A

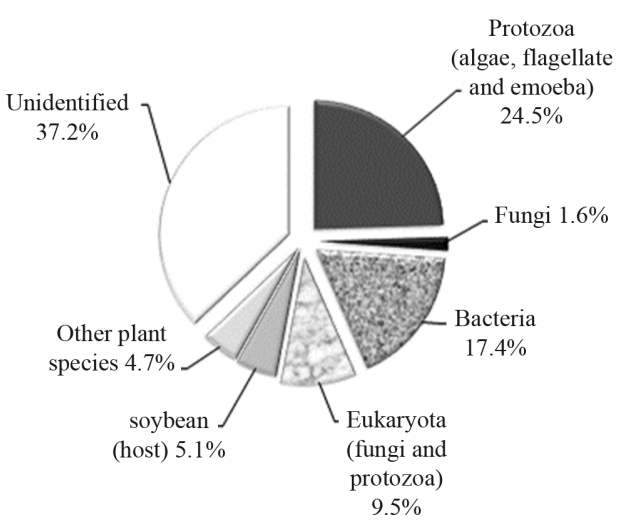

B

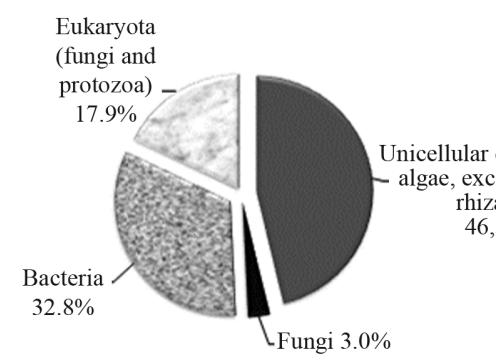

$\mathrm{C}$
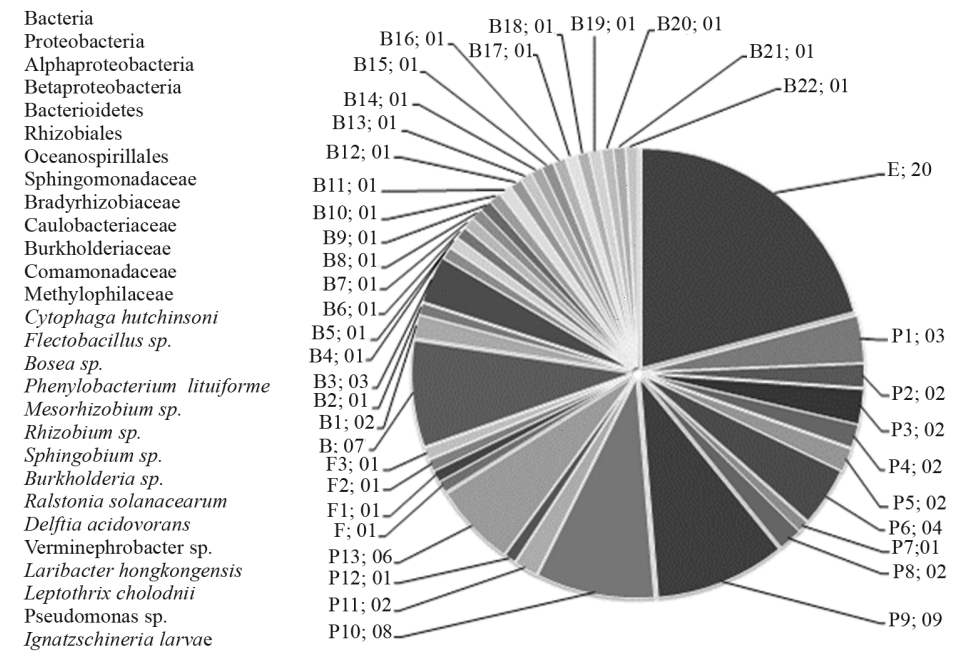

E Eukaryota

P1 Heterolontophyta (Str

P2 Kinetoplastida

P3 Bodonidae

P4 Chrysophyceae

P5 Trypanosomatidae

P6 Cercomonas sp.

P7 Chrysolepidomonas d

P8 Mallomonas sp.

P9 Naegleria sp.

10 Neobodo designis

P11 Pyramimonas sp.

P12 Rhynchomonas nasut:

P13 Spumella $\mathrm{sp}$

F Fungi

F1 Dikarya

F2 Acaulospora scrobicu.

F3 Rozella sp.

Figure 3 - Comparative percentages of the contigs assembled from sRNA (19-24 nt) libraries of the soybean cultivated in a controlled environment for each sequence classification according to best hit with BLASTn. (A) All groups of organisms, (B) all groups excluding unidentified and plants and (C) best identified taxonomic groups.

fied through two contigs. The genera Chrysolepidomonas and Spumella (class Chrysophyceae) were represented by one and seven contigs, respectively. One contig was assigned and classified as pertaining to Spumella elongata. The genus Mallomonas was also identified within the kingdom Chromalveolata (group Heterokontophyta).

Microalgae belonging to kingdom Plantae were represented by the genera Chlorococcum and Pyramimonas. The phylum Cercozoa belonging to kingdom Rhizaria was represented by six contigs, with four pertaining to the genus Cercomonas and one to the genus Gymnophrys.

The kingdom Fungi was poorly represented in the controlled environment libraries (Figures 3B, C). One contig was assigned to the genus Rozella and another one to the genus Acaulospora (Figure 4B). We also found a contig with $94 \%$ of identity to an uncultured soil fungus and one with multiple affiliations within the subkingdom Dikarya (Table 1).

The domain Bacteria was the most diverse taxon in controlled environment samples (Figures 3B,C). Contigs affiliated with multiple taxa could be classified only to the domain Bacteria, phyla Bacterioidetes and Proteobacteria, class Alphaproteobacteria and families Sphingomonadaceae, Bradyrhizobiaceae, Caulobacteriaceae, Burkholderiaceae and Comamonadaceae.

The classes Alpha- and Gammaproteobacteria were equally represented, followed by Betaproteobacteria. Within the class Alphaproteobacteria, contigs corresponded to the order Rhizobiales, including the genera Bosea, Rhizobium and Mesorhizobium. There were contigs assigned to families Caulobacteriaceae and Sphingomonadaceae, including the genera Phenylobacterium and Sphingobium, respectively (Figure 4A).

Within the class Gammaproteobacteria, contigs were derived from the order Burkholderiales, families Burkholderiaceae (including Burkholderia and Ralstonia solanacearum) and Comamonadaceae (including the genus Verminephrobacter and the species Delftia acidovorans) and genus Leptothrix. The group Oceanospirillales was represented by a single contig. Within the group Pseudomonadales, the genus Pseudomonas was the only one to be identified with a single contig. The group Xanthomona- 


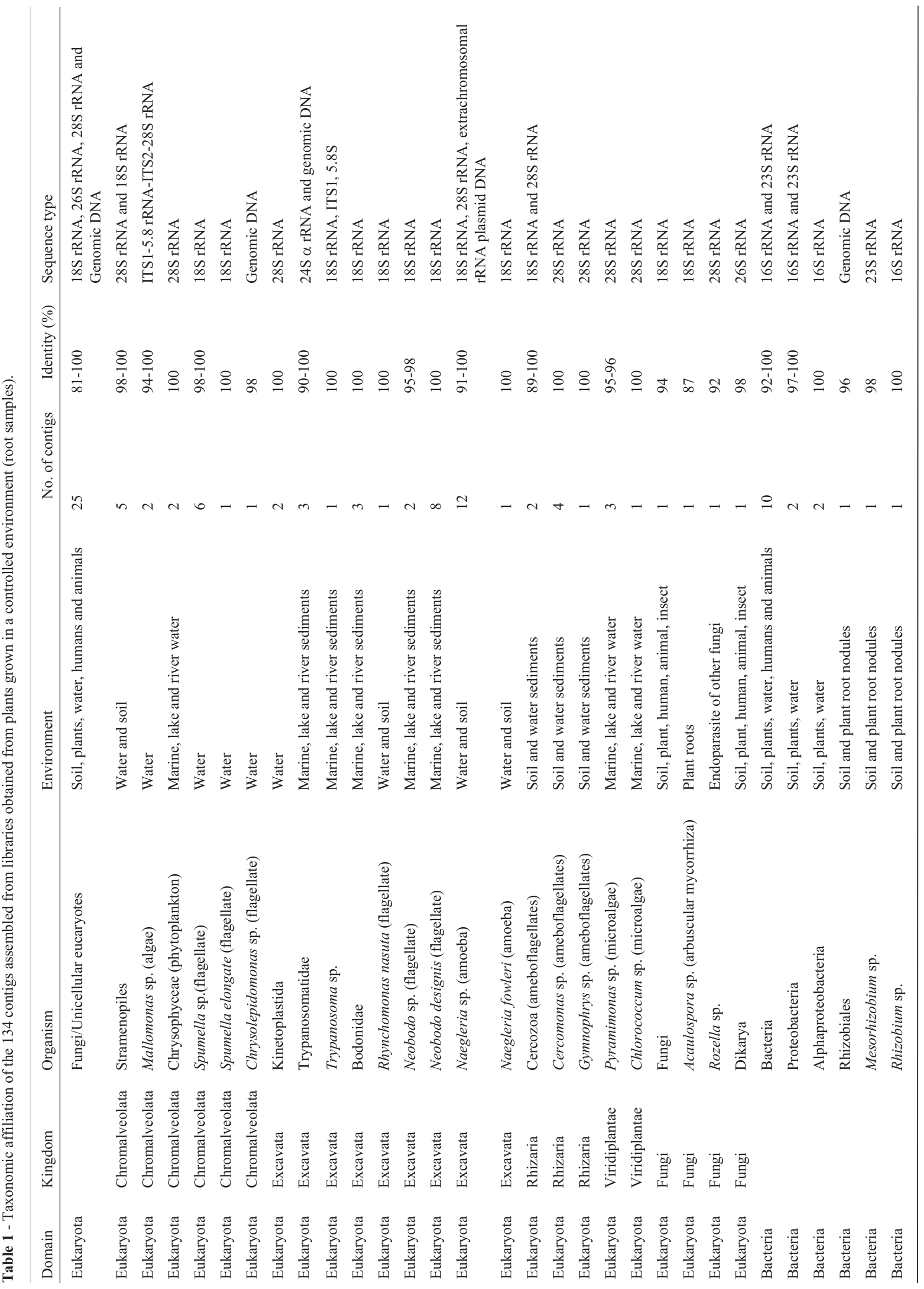



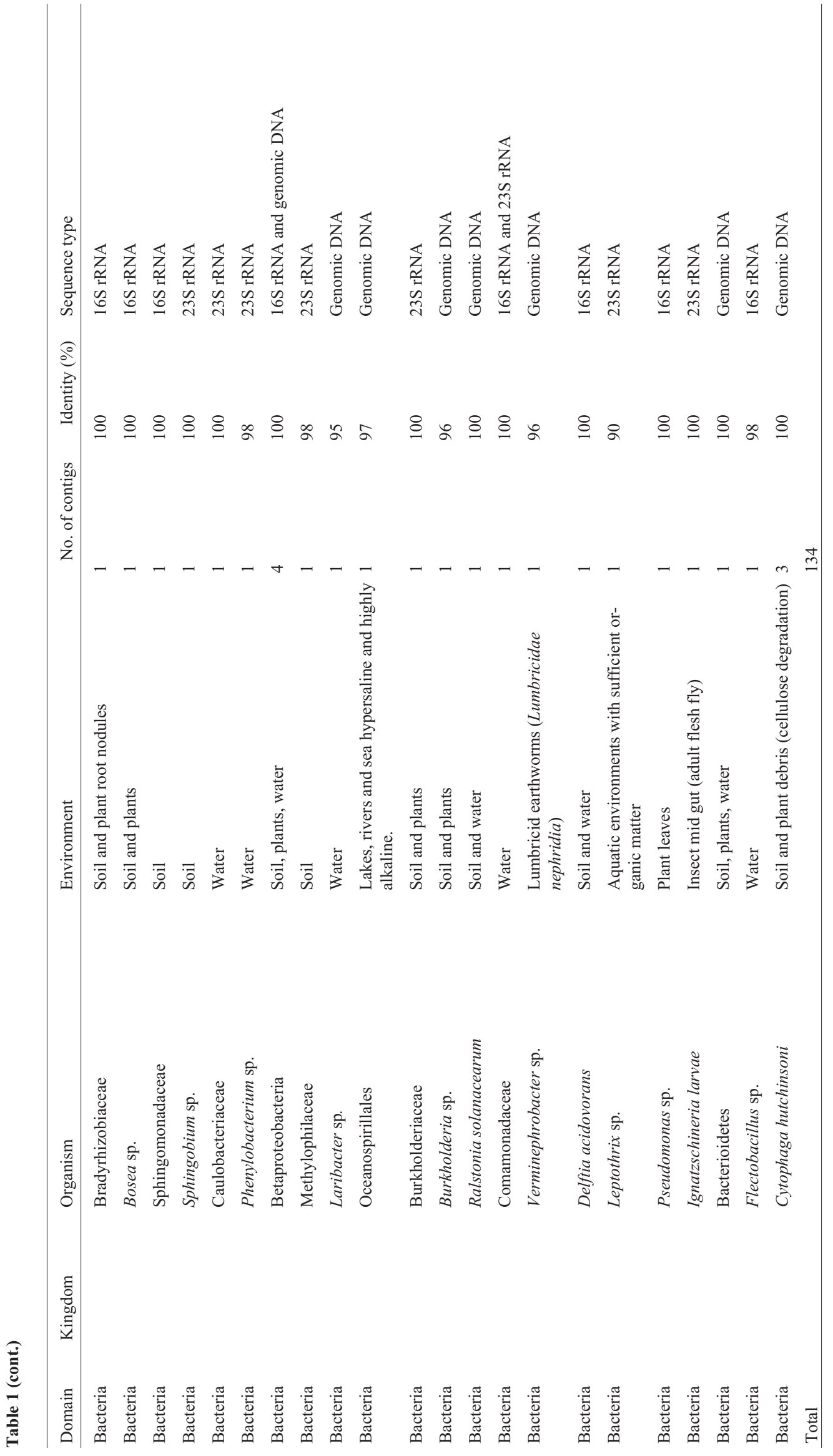


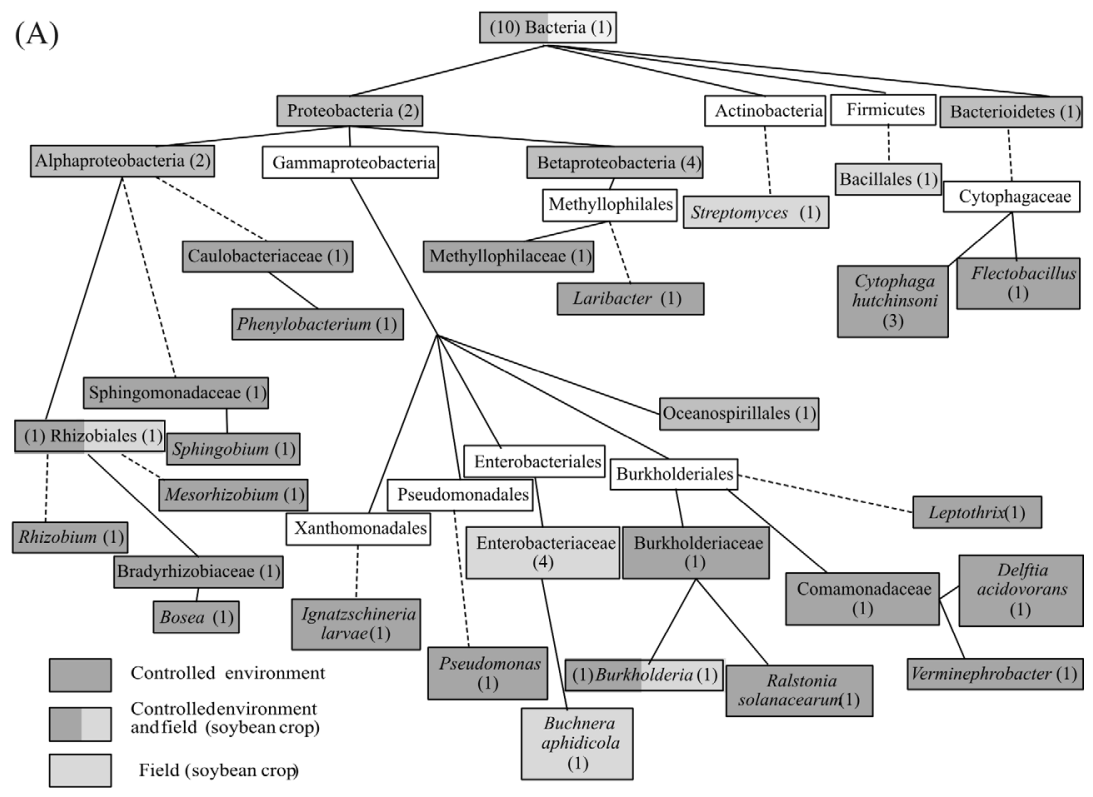

(B)
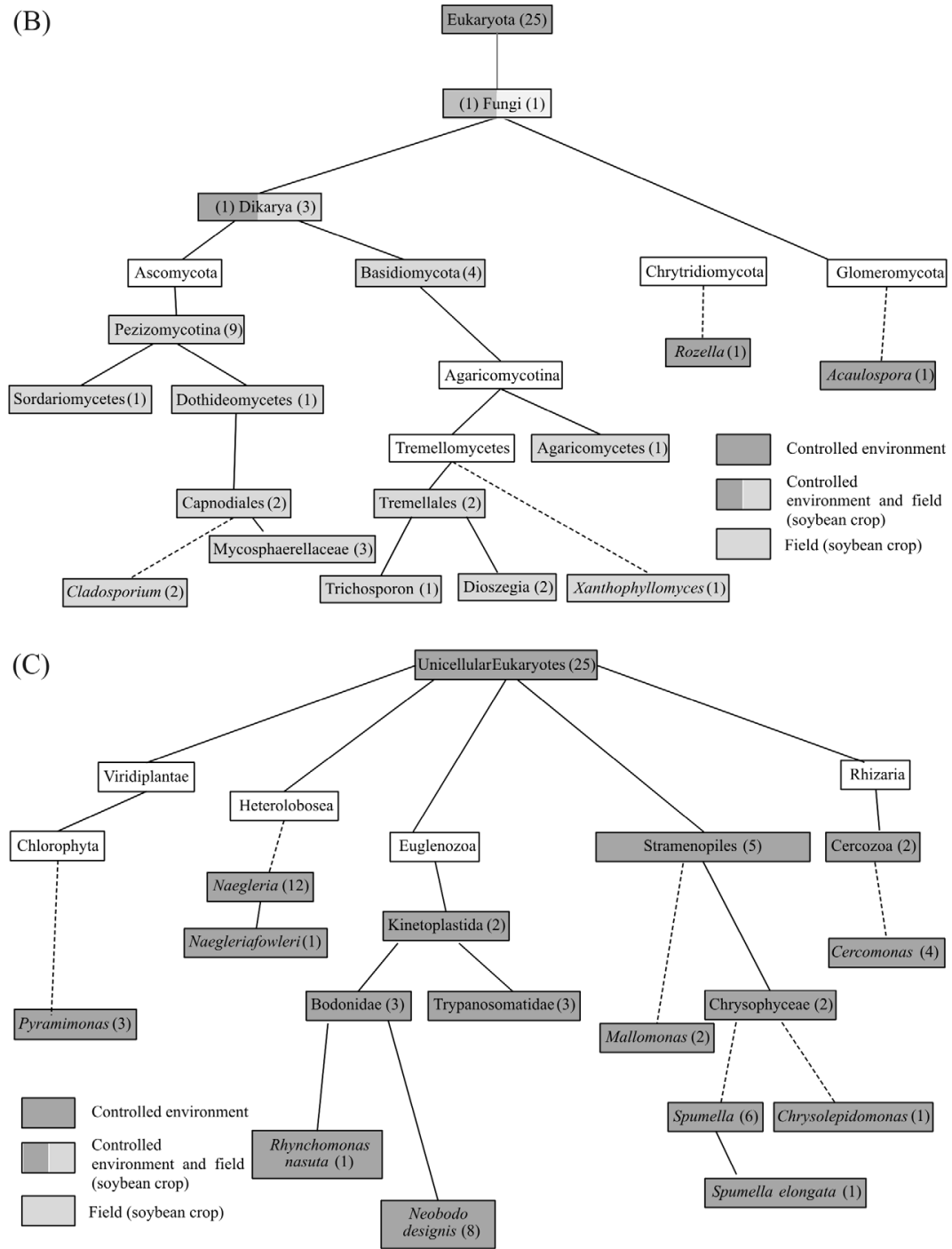

Figure 4 - Taxonomic levels of microorganisms distributed among the libraries of small RNAs in soybean cultivated in a controlled environment and in the field. (A) Bacteria (B) Fungi and (C) other Eukaryota. 
dales was represented by the species Ignatzschineria larvae (Figure 4), and the phylum Bacterioidetes by the species Cytophaga hutchinsoni and genus Flectobacillus, both members of the family Cytophagaceae (Figure 4).

Further contigs were classified at the genus leve and shared high identity (at least $87 \%$ ) to nucleotide sequences of species deposited in the NCBI database (Supplementary Material, Table S1). These may belong to the same or a closely related species, viz. the unicellular eukaryotes Naegleria gruberi, Mallomonas asmundae and Chrysolepidomonas dendrolepidota, the bacteria Phenylobacterium lituiforme, Laribacter hongkongensis and Leptothrix cholodnii, and the fungus Acaulospora scrobiculata.

\section{Taxonomic origin of sRNAs from field samples}

The BLAST analysis revealed that $87.2 \%$ of the contigs assembled from field samples were related to BPMV (Bean Pod Mottle Virus) (Figure 2B). These contigs were assembled from seed and pod samples and showed identities ranging from 94 to $100 \%$ for both RNA1 and RNA2 sequences from the virus (Table 2). The remaining sequences were fungi $(9.9 \%)$ and bacteria (3.0\%).

Within the kingdom Fungi, contigs were classified according to the subkingdom Dikarya and phylum Basidiomycota. One contig was assigned within the phylum Basidiomycota, subphylum Agaricomycetes, and two contigs were assigned to the order Tremellales. Within the order Tremellales, two contigs represented the genus Dioszegia and one contig the genus Trichosporon (Figure 4B). In addition, one contig was not identical but showed high identity (94\%) to the species Xanthophyllomyces dendrorhous and could be classified only in the genus Xanthophyllomyces (Table 2) which belongs to the class Tremellomycetes.

The phylum Ascomycota subphylum Pezizomycotina was the most represented fungal taxon (Figure 2C). It was identified through nine contigs that had multiple affiliations within this taxon, these being with the classes Sordariomycetes and Dothideomycetes. Within this latter there were contigs affiliated to the order Capnodiales, including the family Mycosphaerellaceae and the genus Cladosporium (Figure 4B).

A single contig was classified only at the domain level Bacteria. There were contigs to the class Gammaproteobacteria, one to the genus Burkholderia and four to the family Enterobacteriaceae, including one to Buchnera aphidicola. There were also contigs associated with the class Alphaproteobacteria (order Rhizobiales) and the phyla Firmicutes (order Bacillales) and Actinobacteria from the genus Streptomyces (Figures 2 and 4A, Table 2).

\section{Discussion}

High-throughput sequencing allows the direct sequencing of DNA or cDNA from the environment, avoiding any cloning bias and also being less costly and faster than the Sanger method (Cardenas and Tiedje, 2008). The Illumina (Solexa) technology is capable of generating 36 million reads with average length of 35 bp within 4 days, which is several times higher than the output of traditional cloning libraries. The short read lengths are compensated by massive output, speed, simplicity and coverage, including regions recalcitrant to cloning.

To obtain ribosomal sequences (commonly used in the identification of species) from complex microbial communities, classical polymerase chain reaction (PCR) has been used with primers complementary to highly conserved regions of rRNA (Rosen et al. 2009), representing the bias of being a targeted approach (Bailly et al., 2007).

Because the new sequencing technologies have the potential to sequence technically difficult regions, such as those that form firm secondary structures, they are useful in the analysis of rRNA (Cardenas and Tiedje, 2008).

The metagenomic analysis of sRNA high-throughput libraries, as done in this study, is a non-targeted approach that avoids amplification steps and the design of the 'universal primers'. In this way, the present study provided several rRNA sequences that could be used in taxonomic identification (Tables 1 and 2).

Here, we demonstrate the feasibility of metatranscriptomics/metagenomics to study the microbial communities present in soybean plants cultivated in field and controlled environment. In this work, high-throughput sequencing generated several records for bacteria, fungi, unicellular eukaryotes, and viruses at different taxonomic levels (species, genus, family, order, class, phylum, kingdom or domain).

In root tissues of soybean plants cultivated in a controlled environment, three groups of organisms were detected, these being unicellular eukaryotes, bacteria and fungi. The unicellular eukaryotes were the most abundant group of organisms in root tissues of soybean cultivated in a controlled environment. Unicellular eukaryotes included some subgroups of eukaryote microorganisms, such as microalgae (genera Pyramimonas and Chlorococcum, these belonging to the division Chlorophyta, kingdom Plantae, and the genus Mallomonas belonging to the phylum Heterokontophyta or Stramenopiles, kingdom Chromalveolata), flagellates (including Neobodo designis, Rhynchomonas nasuta and the genus Trypanosoma, belonging to the class Kinetoplastida, kingdom Excavata, and the genus Spumella belonging to the phylum Heterokontophyta or Stramenopiles, kingdom Chromalveolata), amoeba (genus Naegleria, including $N$. loweri, belonging to the class Heterolobosea, kingdom Excavata), and ameboflagellates (genera Cercomonas and Gymnophrys belonging to the phylum Cercozoa, kingdom Rhizaria), which are freeliving organisms in freshwater, soil and marine habitats (Bailly et al., 2007). The fact that plants grown in a controlled environment were cultivated in a hydroponic system with nutritive solution could explain the high percentage of 
Table 2 - Taxonomic affiliation of the 335 contigs assembled from libraries obtained from soybean plants grown in the field (flowers, pods, mature seeds and samples of germinating seeds).

\begin{tabular}{|c|c|c|c|c|c|c|}
\hline Domain & Kingdom & Organism & Environment & No. of contigs & Identity (\%) & Sequence type \\
\hline Eukaryota & Fungi & & $\begin{array}{l}\text { Soil, dung, plant, decaying } \\
\text { wood, fungal, insect, human }\end{array}$ & 1 & 100 & 18S rRNA \\
\hline Eukaryota & Fungi & Dikarya & $\begin{array}{l}\text { Soil, dung, plant, rock, decaying } \\
\text { wood, fungal, insect, human }\end{array}$ & 3 & 100 & $\begin{array}{l}\text { 18S, ITS } 1,5.8 \mathrm{~S} \\
\text { rRNA, ITS 2, 28S rRNA }\end{array}$ \\
\hline Eukaryota & Fungi & Basidiomycota & $\begin{array}{l}\text { Plant, humans, animals, wa- } \\
\text { ter, soil }\end{array}$ & 4 & 100 & $\begin{array}{l}18 \mathrm{~S} \text { rRNA and } 28 \mathrm{~S} \\
\text { rRNA }\end{array}$ \\
\hline Eukaryota & Fungi & Agaricomycetes & Plant, plant debris & 1 & 100 & 28S rRNA \\
\hline Eukaryota & Fungi & $\begin{array}{l}\text { Xanthophyllomyces sp. } \\
\text { (yeast) }\end{array}$ & Plant & 1 & 94 & $28 \mathrm{~S}$ rRNA \\
\hline Eukaryota & Fungi & Tremellales & Human, parasites of other fungi & 2 & 100 & $\begin{array}{l}\text { 5.8S rRNA } \\
\text { gene, ITS2, 26S rRNA }\end{array}$ \\
\hline Eukaryota & Fungi & $\begin{array}{l}\text { Trichosporon sp. } \\
\text { (yeasts) }\end{array}$ & Soil, human & 1 & 100 & 18S rRNA \\
\hline Eukaryota & Fungi & Dioszegia sp. (yeasts) & Plant & 2 & 100 & 26S rRNA, 18S rRNA \\
\hline Eukaryota & Fungi & Pezizomycotina & Plants, soil, debris plant, rock & 9 & 100 & $\begin{array}{l}\text { 18S rRNA gene, ITS1, } \\
\text { 5.8S rRNA, ITS 2, } 28 \mathrm{~S} \\
\text { rRNA }\end{array}$ \\
\hline Eukaryota & Fungi & Sordariomycetes & $\begin{array}{l}\text { Soil, dung, plant, decaying } \\
\text { wood, fungal, insect, human }\end{array}$ & 1 & 100 & $28 \mathrm{~S}$ rRNA \\
\hline Eukaryota & Fungi & Dothideomycetes & Plants, soil, debris plant, rock & 1 & 100 & 28S rRNA \\
\hline Eukaryota & Fungi & Capnodiales & Plants, soil, debris plant, rock & 2 & $97-100$ & $\begin{array}{l}18 \mathrm{~S} \text { rRNA and } 28 \mathrm{~S} \\
\text { rRNA }\end{array}$ \\
\hline Eukaryota & Fungi & Mycosphaerellaceae & Plants, soil, debris plant & 3 & 100 & $\begin{array}{l}18 \mathrm{~S} \text { rRNA and } 28 \mathrm{~S} \\
\text { rRNA }\end{array}$ \\
\hline Eukaryota & Fungi & Cladosporium sp. & Plants, soil, debris plant & 2 & $98-100$ & 18S rRNA \\
\hline Bacteria & & Bacteria & $\begin{array}{l}\text { Plant, humans, animals, wa- } \\
\text { ter, soil }\end{array}$ & 1 & 100 & 16S rRNA \\
\hline Bacteria & & Rhizobiales & Soil and root plant nodules & 1 & 100 & 16S rRNA \\
\hline Bacteria & & Enterobacteriaceae & $\begin{array}{l}\text { Plant, humans, animals, wa- } \\
\text { ter, soil }\end{array}$ & 4 & 100 & $\begin{array}{l}16 \mathrm{~S} \text { rRNA, } 23 \mathrm{~S} \text { rRNA } \\
\text { and genomic DNA }\end{array}$ \\
\hline Bacteria & & Buchnera aphidicola & Insect & 1 & 100 & Genomic DNA \\
\hline Bacteria & & Burkholderia sp. & Soil, plant, human & 1 & 100 & Chromosome 2 \\
\hline Bacteria & & Streptomyces sp. & Plant & 1 & 100 & 16S rRNA \\
\hline Bacteria & & Bacillales & $\begin{array}{l}\text { Plant, humans, animals, wa- } \\
\text { ter, soil }\end{array}$ & 1 & 100 & $23 \mathrm{~S}$ rRNA \\
\hline Aphanabionta & & Bean pod mottle virus & Plant & 292 & $94-100$ & $\begin{array}{l}\text { RNA1, soy RNA1-b po- } \\
\text { lyprotein, RNA2, puta- } \\
\text { tive defective coat pro- } \\
\text { tein, capsid polyprotein }\end{array}$ \\
\hline Total & & & & 335 & & \\
\hline
\end{tabular}

unicellular eukaryotes found in this habitat, since these organisms feed on the sediment of organic matter present in water.

The domain Bacteria was the second highest group in terms of occurrence in root samples, including endophytic and epiphytic bacteria. Species, genera, families, and orders related to growth promotion and nodulation through endosymbiosis with rhizobia (Juteau et al., 2004; Kuklinsky-Sobral et al., 2004; Delmotte et al., 2009; Ikeda et al., 2009, 2010; Okubo et al., 2009) were found in this work
(Table S1). They include the genera Rhizobium, Mesorhizobium, Sphingobium, Burkholderia, Bosea and Pseudomonas, the families Bradyrhizobiaceae, Sphingomonadaceae and Rhizobiaceae, and the order Rhizobiales. We also found some species and genera involved in the degradation of cellulose in plant debris and that of organic matter in humid and freshwater habitats, such as the species/genera Cytophaga hutchinsoni, Delftia acidovorans, Ignatzschineria larvae, Laribacter (Woo et al., 2009), Leptothrix and Phenylobacterium. 
Ralstonia solanacearum is considered a bacterial pathogen. It causes wilt in important crops (including soybean) in other countries. Nevertheless, populations of Ralstonia solanacearum may occur as free-living microorganisms in watercourses or in a latent form in plants without causing disease (Grey and Steck, 2001; Mole et al., 2007). The genus Pseudomonas identified in this study includes members that are pathogenic to soybean, such as $P$. syringae pv. glycinea, or non-pathogenic ones, surviving as saprophytes, epiphytes or endophytes (Kuklinsky-Sobral et al., 2004).

Endophytic and epiphytic bacteria can contribute to the health, growth and development of plants. Promotion of plant growth by these bacteria may result from indirect effects, such as the biocontrol of soilborne diseases through competition for nutrients, siderophore-mediated competition for iron, antibiosis, or the induction of systemic resistance in the host plant. Direct effects, such as the production of phytohormones, providing the host plant with fixed nitrogen, or solubilization of phosphorus and iron present in soil, may also be of relevance (Kuklinsky-Sobral et al., 2004).

The bacterial families Commamonadaceae and Caulobacteriaceae have members involved in sediment degradation in freshwater. Other groups of bacteria, such as members of the family Methylophilaceae and the order Oceanospirillales can survive in soil and humid habitats.

Fungi present in the roots of soybean plants were found to belong to the genus Rozella, these being involved in the biological control of other fungi in plants. The genus Acaulospora forms arbuscular mycorhiza in plants, thus increasing nutrient absorption from soil, mainly phosphorus.

In seeds, seedlings, pods and flowers from soybean plants cultivated in field (crop), three groups of organisms were identified: virus, fungi and bacteria. The virus group was represented by a single member only, the Bean Pod Mottle Virus (BPMV). This virus is widespread in the major soybean growing areas throughout Brazil and the world (Anjos et al., 2000; Giesler et al., 2002). 0Mottling originates at the hilum and is also referred to as "bleeding hilum" since the hilum color seems to bleed from its normal zone. From then on, the mottling of the seed has similar coloration as the hilum (Giesler et al., 2002). BPMV was detected mainly in the mature seed library of sRNA, and seeds used in the RNA extraction procedure showed symptoms of mottling (data not shown), predicting the occurrence of BPMV infection.

The identified fungi were classified at species, genus, family, order, class, subphylum, and phylum levels. The yeast genera Xanthophyllomyces, Dioszegia and Thichosporon may occur in flower, seed, stem and leaf surfaces, and are essential for biological control of pathogens (Kucsera et al., 1998; Wang et al., 2008; Weber et al., 2008). The genus Cladosporium found in this study in flower and seed tissues of soybean is known to contain entomopathogenic species with potential for biocontrol of pest insects (Pimentel et al., 2006). The family Mycosphaerellaceae was detected in this work. It includes various genera, especially Cercospora, Pseudocercospora, Mycosphaerella, Septoria, Ramularia, etc. that represent more than 10,000 species. The genera Cercospora, Mycosphaerella and Septoria contain some species considered as pathogenic to soybean (Crous et al., 2009). The subkingdom Dikarya, phylum Basidiomycota, subphylum Pezizomycotina, classes Dothideomycetes, Agaricomycetes and Sordariomycetes, and order Tremellales contain both phytopathogenic and nonpathogenic fungi species related to soybean, including species with potential for biocontrol of pest insects and diseases.

Moreover, in the field environment many bacteria were found associated with soybean tissue. The bacterium Buchnera aphidicola colonizes insects and may be present on plant surfaces. The genus Burkholderia includes endophytic species present in soil and plant (Kuklinsky-Sobral et al., 2005). The family Enterobacteriaceae includes many endophytes, such as the genus Pantoea, which occur mainly in leguminous plants involved in biological control of phytopathogens (Delmotte et al., 2009; Ikeda et al., 2010). The orders Rhizobiales and Bacillales contain endophytes and species that colonize the rhizosphere and phyllosphere, and are related to soybean nodulation and biological control of pest insects, fungi and bacteria.

Several contigs could not be classified deeper into the eukaryote domain due to multiple affiliations or hitting to sequences from environmental samples (many from uncultured freshwater eukaryotes) (Table S1).

The high percentage of unknown sequences in this study could correspond to artifacts or to transcript fragments from poorly known taxa. Similarly, in many samples of a metagenomic study of plant viruses (Roossinck et al., 2010), sequences without similarity to GenBank sequences represented more than half of the contigs. Furthermore, in a metatranscriptomic analysis of microbial communities from watercourse, half of the possible protein-encoding sequences from pyrosequencing had no significant hits to previously sequenced genes. The length of the contigs influenced this frequency, as the analysis of larger ( $>200 \mathrm{bp}$ ) sequences resulted in twice the frequency of annotated sequences when compared to shorter $(<100 \mathrm{bp})$ reads (Poretsky et al., 2009).

The sequencing of small RNA molecules in the size range of 19 to 25 was chosen as it corresponds to the sizes of small interfering RNAs (siRNAs) and virus derived interfering RNAs (vsiRNAs). These are normally produced when RNA interference mechanisms are activated in order to degrade endogenous or pathogen-derived RNAs. The size range of the sequenced small RNAs could be enlarged up to 100 nucleotides, in order to include other small RNA molecules originated by other processes of degradation. Sizes under 19 nucleotides should be avoided since they 
would have ambiguous matches in different genomes and would not be useful in species prediction.

The challenges that remain in metagenomics and metatranscriptomics include DNA and RNA extraction, low stability, abundance and proportion of mRNAs in total RNA extracts (Cardenas and Tiedje, 2008). In addition, many of the difficulties encountered in microbial diversity studies are due to the complexity of the microbial community and its unevenness (few populations are of high frequency and many populations of low abundance). These difficulties can be reduced in metatranscriptomics by focusing on the active populations in a sample (Morales and Holben, 2010). When analyzing a soil microbial community, Urich et al. (2008) demonstrated that the deepsequencing data from total RNA is naturally enriched in both functionally (such as mRNA libraries) and taxonomically relevant molecules, i.e. mRNA and rRNA, respectively.

Nevertheless, upon using deep-sequencing data, significant differences have been found in the taxonomic distribution of cDNAs derived from total RNA compared to DNA libraries from soil samples (Bailly et al., 2007). Differences were also found when comparing cDNA derived from mRNA-enriched libraries with DNA libraries from marine microbial communities (Gilbert et al., 2008). This suggests that both DNA and RNA sequences should be analyzed complementarily when investigating the diversity of species from environmental samples. In this sense, sRNA sequencing libraries can contribute to microbial identification with other types of sequences, viz. non-coding RNAs and mRNA fragments that would not normally be present in libraries enriched for polyA-tailed mRNA.

\section{Acknowledgments}

LGM was sponsored by a M.Sc. grant; GCF, GLM, LFVO and FRK by a PhD grant, JBC by a DTI-RHAE and RM by a Productivity and Research grant from the National Council for Scientific and Technological Development (CNPq, Brazil). This work was financially supported by GenoSoja consortium (CNPq 5527/2007-8) and GenoProt (CNPq 559636/2009-1).

\section{References}

Adams IP, Glover RH, Monger WA, Mumford R, Jackeviciene E, Navalinskiene M, Samuitiene M and Boonham N (2009) Next-generation sequencing and metagenomic analysis: A universal diagnostic tool in plant virology. Mol Plant Pathol 10:537-545.

Al Rwahnih M, Daubert S, Golino D and Rowhani A (2009) Deep sequencing analysis of RNAs from a grapevine showing Syrah decline symptoms reveals a multiple virus infection that includes a novel virus. Virology 387:395-401.

Anjos JRN, Charchar MJA and Gomes AC (2000) Identificação do vírus do mosqueado do feijoeiro ("Bean Pod Mottle Vi- rus") em soja no Brasil. Documentos Embrapa Cerrados 19:1-15.

Bailly J, Fraissinet-Tachet L, Verner MC, Debaud JC, Lemaire M, Wesolowski-Louvel M and Marmeisse R (2007) Soil eukaryotic functional diversity, a metatranscriptomic approach. ISME J 1:632-642.

Cardenas E and Tiedje JM (2008) New tools for discovering and characterizing microbial diversity. Curr Opin Biotechnol 19:544-549.

Chistoserdova L (2010) Recent progress and new challenges in metagenomics for biotechnology. Biotechnol Lett 32:13511359.

Coetzee B, Freeborough MJ, Maree HJ, Celton JM, Rees DJ and Burger JT (2010) Deep sequencing analysis of viruses infecting grapevines: Virome of a vineyard. Virology 400:157-163.

Creer S, Fonseca VG, Porazinska DL, Giblin-Davis RM, Sung W, Power DM, Packer M, Carvalho GR, Blaxter ML, Lambshead PJ et al. (2010) Ultrasequencing of the meiofaunal biosphere: Practice, pitfalls and promises. Mol Ecol 19(Suppl 1):4-20.

Crous PW, Summerell BA, Carnegie AJ, Wingfield MJ and Groenewald JZ (2009) Novel species of Mycosphaerellaceae and Teratosphaeriaceae. Persoonia 23:119-146.

Delmotte N, Knief C, Chaffron S, Innerebner G, Roschitzki B, Schlapbach R, von Mering C and Vorholt JA (2009) Community proteogenomics reveals insights into the physiology of phyllosphere bacteria. Proc Natl Acad Sci USA 106:16428-16433.

Desai C, Pathak H and Madamwar D (2010) Advances in molecular and "-omics" technologies to gauge microbial communities and bioremediation at xenobiotic/anthropogen contaminated sites. Bioresour Technol 101:1558-1569.

Giesler LJ, Ghabrial SA, Hunt TE and Hill JH (2002) Bean Pod Mottle Virus: A threat to U.S. soybean production. Plant Disease 86:1280-1289.

Gifford SM, Sharma S, Rinta-Kanto JM and Moran MA (2010) Quantitative analysis of a deeply sequenced marine microbial metatranscriptome. ISME J 5:461-472.

Gilbert JA, Field D, Huang Y, Edwards R, Li W, Gilna P and Joint I (2008) Detection of large numbers of novel sequences in the metatranscriptomes of complex marine microbial communities. PLoS One 3:e3042.

Grey BE and Steck TR (2001) The viable but nonculturable state of Ralstonia solanacearum may be involved in long-term survival and plant infection. Appl Environ Microbiol 67:3866-3872.

Ikeda S, Kaneko T, Okubo T, Rallos LE, Eda S, Mitsui H, Sato S, Nakamura Y, Tabata S and Minamisawa K (2009) Development of a bacterial cell enrichment method and its application to the community analysis in soybean stems. Microb Ecol 58:703-714.

Ikeda S, Okubo T, Anda M, Nakashita H, Yasuda M, Sato S, Kaneko T, Tabata S, Eda S, Momiyama A et al. (2010) Community- and genome-based views of plant-associated bacteria: Plant-bacterial interactions in soybean and rice. Plant Cell Physiol 51:1398-1410.

Juteau P, Tremblay D, Villemur R, Bisaillon JG and Beaudet R (2004) Analysis of the bacterial community inhabiting an aerobic thermophilic sequencing batch reactor (AT-SBR) 
treating swine waste. Appl Microbiol Biotechnol 66:115122.

Kent AD, Yannarell AC, Rusak JA, Triplett EW and McMahon KD (2007) Synchrony in aquatic microbial community dynamics. ISME J 1:38-47.

Kreuze JF, Perez A, Untiveros M, Quispe D, Fuentes S, Barker I and Simon R (2009) Complete viral genome sequence and discovery of novel viruses by deep sequencing of small RNAs: A generic method for diagnosis, discovery and sequencing of viruses. Virology 388:1-7.

Kucsera J, Pfeiffer I and Ferenczy L (1998) Homothallic life cycle in the diploid red yeast Xanthophyllomyces dendrorhous (Phaffia rhodozyma). Antonie Van Leeuwenhoek 73:163168.

Kuklinsky-Sobral J, Araujo WL, Mendes R, Geraldi IO, Pizzirani-Kleiner AA and Azevedo JL (2004) Isolation and characterization of soybean-associated bacteria and their potential for plant growth promotion. Environ Microbiol 6:1244-1251.

Kuklinsky-Sobral J, Araújo WL, Mendes R, Pizzirani-Kleiner AA and Azevedo JL (2005) Isolation and characterization of endophytic bacteria from soybean (Glycine max) grown in soil treated with glyphosate herbicide. Plant Soil 273:91-99.

Li R, Yu1 Y, Li Y, Lam TW, Yiu SM, Kristiansen K and Wang J (2009) SOAP2: An improved ultrafast tool for short read alignment. Bioinformatics 25:1966-1967.

Mole BM, Baltrus DA, Dangl JL and Grant SR (2007) Global virulence regulation networks in phytopathogenic bacteria. Trends Microbiol 15:363-371.

Morales SE and Holben WE (2010) Linking bacterial identities and ecosystem processes: Can "omic" analyses be more than the sum of their parts? FEMS Microbiol Ecol 75:2-16.

Okubo T, Ikeda S, Kaneko T, Eda S, Mitsui H, Sato S, Tabata S and Minamisawa K (2009) Nodulation-dependent communities of culturable bacterial endophytes from stems of field-grown soybeans. Microbes Environ 24:253-258.

Pimentel IC, Glienke-Blanco C, Gabardo J, Stuart RM and Azevedo JL (2006) Identification and colonization of endophytic fungi from soybean (Glycine $\max (\mathrm{L}$.) Merril) under different environmental conditions. Braz Arch Biol Technol 49:705-711.

Poretsky RS, Hewson I, Sun S, Allen AE, Zehr JP and Moran MA (2009) Comparative day/night metatranscriptomic analysis of microbial communities in the North Pacific subtropical gyre. Environ Microbiol 11:1358-1375.

Roossinck MJ, Saha P, Wiley GB, Quan J, White JD, Lai H, Chavarria F, Shen G and Roe BA (2010) Ecogenomics: Using massively parallel pyrosequencing to understand virus ecology. Mol Ecol 19(Suppl 1):81-88.

Rosen GL, Sokhansanj BA, Polikar R, Bruns MA, Russell J, Garbarine E, Essinger S and Yok N (2009) Signal processing for metagenomics: Extracting information from the soup. Curr Genomics 10:493-510.
Shi Y, Tyson GW and DeLong EF (2009) Metatranscriptomics reveals unique microbial small RNAs in the ocean's water column. Nature 459:266-269.

Urich T, Lanzen A, Qi J, Huson DH, Schleper C and Schuster SC (2008) Simultaneous assessment of soil microbial community structure and function through analysis of the metatranscriptome. PLoS One 3:e2527.

Wang QM, Jia JH and Bai FY (2008) Diversity of basidiomycetous phylloplane yeasts belonging to the genus Dioszegia (Tremellales) and description of Dioszegia athyri sp. nov., Dioszegia butyracea sp. nov. and Dioszegia xingshanensis sp. nov. Antonie Van Leeuwenhoek 93:391399.

Warnecke F and Hess M (2009) A perspective: Metatranscriptomics as a tool for the discovery of novel biocatalysts. J Biotechnol 142:91-95.

Weber RW, Becerra J, Silva MJ and Davoli P (2008) An unusual Xanthophyllomyces strain from leaves of Eucalyptus globulus in Chile. Mycol Res 112:861-867.

Woo PC, Lau SK, Tse H, Teng JL, Curreem SO, Tsang AK, Fan RY, Wong GK, Huang Y, Loman NJ et al. (2009) The complete genome and proteome of Laribacter hongkongensis reveal potential mechanisms for adaptations to different temperatures and habitats. PLoS Genet 5:e1000416.

$\mathrm{Xu} J$ (2006) Microbial ecology in the age of genomics and metagenomics: Concepts, tools, and recent advances. Mol Ecol 15:1713-1731.

Zerbino DR and Birney E (2008) Velvet: Algorithms for de novo short read assembly using de Bruijn graphs. Genome Res 18:821-829.

Zoetendal EG, Rajilic-Stojanovic M and de Vos WM (2008) High-throughput diversity and functionality analysis of the gastrointestinal tract microbiota. Gut 57:1605-1615.

\section{Internet Resources}

Phytozome, ftp://ftp.jgi-psf.org/pub/JGI_data/phytozome/v6.0/Gmax/as sembly/sequence/.

\section{Supplementary Material}

The following online material is available for this article:

Tables S1 - Relationship among metatranscriptomic sequencing data and species sequences in public data banks

This material is available as part of the online article from http://www.scielo.br/gmb.

License information: This is an open-access article distributed under the terms of the Creative Commons Attribution License, which permits unrestricted use, distribution, and reproduction in any medium, provided the original work is properly cited. 
Table. S1. Relationship among metatranscriptomic sequencing data and species sequences in public data Banks.

\begin{tabular}{|c|c|c|c|c|c|c|c|c|c|c|c|}
\hline Class & Order & Family & Genus & Specie & Taxon & $\begin{array}{c}\text { Gene } \\
\text { sequence }\end{array}$ & $\begin{array}{l}\text { Acession } \\
\text { Genbank }\end{array}$ & E-value & $\begin{array}{l}\text { Length } \\
\text { (bp) }\end{array}$ & $\begin{array}{l}\text { Query } \\
\text { (\%) }\end{array}$ & $\begin{array}{l}\text { Max } \\
\text { Identity } \\
\text { (\%) }\end{array}$ \\
\hline Sphingobacteria & Sphingobacteriales & Cytophagaceae & Cytophaga & $\begin{array}{l}\text { Cytophaga } \\
\text { hutchinsoni }\end{array}$ & $\begin{array}{l}\text { Bacteria; Bacteroidetes; } \\
\text { Sphingobacteria; } \\
\text { Sphingobacteriales; Cytophagaceae; } \\
\text { Cytophaga hutchinsoni }\end{array}$ & $\begin{array}{l}\text { Genomic } \\
\text { DNA }\end{array}$ & CP000383.1 & $5,00 E-019$ & 55 & 100 & 100 \\
\hline Sphingobacteria & Sphingobacteriales & Cytophagaceae & Cytophaga & $\begin{array}{l}\text { Cytophaga } \\
\text { hutchinsoni }\end{array}$ & $\begin{array}{l}\text { Bacteria; Bacteroidetes; } \\
\text { Sphingobacteria; } \\
\text { Sphingobacteriales; Cytophagaceae; } \\
\text { Cytophaga hutchinsoni }\end{array}$ & $\begin{array}{l}\text { Genomic } \\
\text { DNA }\end{array}$ & CP000383.1 & $7,00 \mathrm{E}-023$ & 62 & 100 & 100 \\
\hline Sphingobacteria & Sphingobacteriales & Cytophagaceae & Cytophaga & $\begin{array}{l}\text { Cytophaga } \\
\text { hutchinsoni }\end{array}$ & $\begin{array}{l}\text { Bacteria; Bacteroidetes; } \\
\text { Sphingobacteria; } \\
\text { Sphingobacteriales; Cytophagaceae; } \\
\text { Cytophaga hutchinsoni }\end{array}$ & $\begin{array}{l}\text { Genomic } \\
\text { DNA }\end{array}$ & СР000383.1 & 3,00E-017 & 51 & 100 & 100 \\
\hline \multirow[t]{2}{*}{ Sphingobacteria } & Sphingobacteriales & Cytophagaceae & Flectobacillus & $\begin{array}{l}\text { Flectobacillus } \\
\text { sp. }\end{array}$ & $\begin{array}{l}\text { Bacteria; Bacteroidetes; } \\
\text { Sphingobacteria; } \\
\text { Sphingobacteriales; Cytophagaceae: } \\
\text { Flectobacillus sp. environmental } \\
\text { samples. }\end{array}$ & $16 \mathrm{~S}$ rRNA & HQ111157.1 & $9,00 \mathrm{E}-022$ & 63 & 100 & 98 \\
\hline & & & & & $\begin{array}{l}\text { Bacteria; Bacteroidetes; } \\
\text { Sphingobacteria; } \\
\text { Sphingobacteriales;Sphingobacteria } \\
\text { ceae; Sphingobacterium sp. } \\
\text { (environmental samples);Bacteria; } \\
\text { Bacteroidetes; Flavobacteria; } \\
\text { Flavobacteriales; }\end{array}$ & $\begin{array}{l}\text { Genomic } \\
\text { DNA }\end{array}$ & GU925156.1 & $1,00 \mathrm{E}-020$ & 58 & 100 & 100 \\
\hline Alphaproteobacteria & Rhizobiales & Bradyrhizobiaceae & Bosea & Bosea sp. & $\begin{array}{l}\text { Bacteria; Proteobacteria; } \\
\text { Alphaproteobacteria; } \\
\text { Rhizobiales;Bradyrhizobiaceae; } \\
\text { Bosea sp. }\end{array}$ & 16S rRNA & HQ260890.1 & $1,00 \mathrm{E}-023$ & 63 & 98 & 100 \\
\hline Alphaproteobacteria & Rhizobiales & Bradyrhizobiaceae & & & $\begin{array}{l}\text { Bacteria; Proteobacteria; } \\
\text { Alphaproteobacteria; Rhizobiales; } \\
\text { Bradyrhizobiaceae: Bosea sp.; } \\
\text { Bacteria; Proteobacteria; } \\
\text { Alphaproteobacteria; Rhizobiales; } \\
\text { Bradyrhizobiaceae; uncultured } \\
\text { alphaproteobacterium }\end{array}$ & 16S rRNA & $\underline{\mathrm{HQ} 259685.1}$ & $7,00 \mathrm{E}-018$ & 53 & 100 & 100 \\
\hline Alphaproteobacteria & Caulobacteriales & Caulobacteriaceae & $\begin{array}{l}\text { Phenylobacteri } \\
\text { um }\end{array}$ & $\begin{array}{l}\text { Phenylobacte } \\
\text { rium } \\
\text { lituiforme }\end{array}$ & $\begin{array}{l}\text { Bacteria; Proteobacteria; } \\
\text { Alphaproteobacteria; } \\
\text { Caulobacterales; Caulobacteraceae; }\end{array}$ & $23 \mathrm{~S}$ rRNA & DQ306696.1 & $5,00 E-021$ & 61 & 100 & 98 \\
\hline
\end{tabular}




\section{Bacteria; Proteobacteria;}

Alphaproteobacteria;

$\begin{array}{lllllll}\text { Caulobacterales; Caulobacteraceae: } & 235 \text { rRNA } & \text { CP000747.1 } & 1,00 E-024 & 65 & 100 & 100\end{array}$

Alphaproteobacteria Caulobacteriales Caulobacteriaceae

Phyllobacteriaceae

Mesorhizobium

Mesorhizobiu

$m s p$.

Brevundimonas sp.; Caulobacter sp.

Bacteria; Proteobacteria;

Alphaproteobacteria Rhizobiales

Rhizobiaceae

Rhizobium

Alphaproteobacteria Rhizobiales

Rhizobium sp.

Alphaproteobacteria; Rhizobiales;

Phyllobacteriaceae; Mesorhizobium

sp.

Bacteria; Proteobacteria;

Alphaproteobacteria;

Rhizobiales; Rhizobiaceae;

Rhizobium/Agrobacterium group

Rhizobium sp.

Bacteria; environmental samples:

uncultured bacteria;

Alphaproteobacteria Sphingomonadales Sphingomonadaceae Sphingobium

Sphingobium Proteobacteria;

$s p$.

Alphaproteobacteria

23S rRNA GU925159.1 5,00E-024

100

98

Sphingomonadales;Sphingomonada

ceae; Sphingobium sp.

Bacteria; Proteobacteria;

Alphaproteobacteria

Sphingomonadales;

Sphingomonadaceae:

Sphingomonas sp;

Novosphingobium sp.

Bacteria; Proteobacteria;

Alphaproteobacteria;

environmental samples: uncultured

alphaproteobacteria.

Bacteria; Proteobacteria;

Alphaproteobacteria; Uncultured

bacterium; Bacteria;

Proteobacteria;

Alphaproteobacteria;

Sphingomonadales;

Sphingomonadaceae;

Novosphingobium; environmental

samples

Bacteria; Proteobacteria

Alphaproteobacteria;

Rhizobiales;Methylobacteriaceae

Methylobacterium sp.;Bacteria;

Proteobacteria;

Genomic

DNA

СР000943.1

2,00E-014

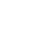

51 
Alphaproteobacteria;

Rhizobiales;Xanthobacteraceae

Xanthobacter autotrophicus

Bacteria; Proteobacteria;

$\begin{array}{llll}\text { Betaproteobacteria Burkholderiales Burkholderiaceae Burkholderia } & \begin{array}{l}\text { Burkholderia } \\ s p .\end{array}\end{array}$

Betaproteobacteria;

Burkholderiales; Burkholderiaceae;

Genomic

Burkholderia sp.

Bacteria; Proteobacteria;

Betaproteobacteria Burkholderiales Burkholderiaceae Ralstonia

Ralstonia Betaproteobacteria;

Burkholderiales;Burkholderiaceae

DNA

CP002014.1 4,00E-014

52

100

96

solanacearum

Ralstonia solanacearum

Bacteria; Proteobacteria;

Betaproteobacteria;

Burkholderiales;

Genomic

DNA

FP885906

7,00E-02

66

6

100

100

Betaproteobacteria Burkholderiales Burkholderiaceae

Burkholderiaceae: Ralstonia

23S rRNA $\quad$ FP885906.2 $\quad 4,00 E-020 \quad 60 \quad 95$

100

solanacearum, Burkholderia sp.

Bacteria; Proteobacteria;

$\begin{array}{llll}\text { Betaproteobacteria Burkholderiales Comamonadaceae Delftia } & \begin{array}{l}\text { Delftia } \\ \text { acidovorans }\end{array}\end{array}$

Betaproteobacteria;

acidovorans Burkholderiales; Comamonadaceae;

$16 \mathrm{~S}$ rRNA

A

Delftia acidovorans

Bacteria; Proteobacteria;

Betaproteobacteria Burkholderiales Comamonadaceae Verminephroba Verminephro Betaproteobacteria;

cter bactersp. Burkholderiales; Comamonadaceae;

Genomic

Verminephrobacter sp.

Bacteria; Proteobacteria;

Betaproteobacteria;

Burkholderiales;Comamonadaceae: $16 \mathrm{~S}$ rRNA

Comamonas sp.; Curvibacter sp.; rRNA

Variovorax sp.; Acidovorax sp.;

Delftia sp.

Bacteria; Proteobacteria;

Betaproteobacteria;

$\begin{array}{llllll}\text { Methylophilales; Methylophilaceae: } & \text { 23S rRNA } & \text { CP002056.1 } & 7,00 E-028 & 75 & 98\end{array}$

Methylotenera sp. Methylovorus

sp.

Betaproteobacteria Methylophilales Methylophilaceae

Bacteria; Proteobacteria;

Betaproteobacteria Neisseriales Neisseriaceae Laribacter $\begin{aligned} & \text { Laribacter } \\ & \text { hongkongensi } \\ & s\end{aligned}$

Betaproteobacteria Neisse

Neisseriaceae; Laribacter

hongkongensis.

Bacteria; Proteobacteria;

Betaproteobacteria Burkholderiales

Leptothrix

Leptothrix Betaproteobacteria;

cholodnii Burkholderiales; Leptothrix

cholodnii

Bacteria; environmental samples:

uncultured bacteria; Bacteria;

Proteobacteria;

Genomic

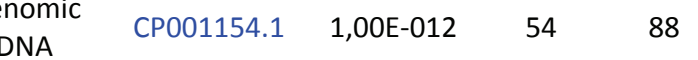

Betaproteobacteria

Betaproteobacteria. 
Bacteria; Proteobacteria;

Betaproteobacteria:Uncultured

beta proteobacterium

Betaproteobacteria

(environmental samples);Bacteria;

Proteobacteria;

Genomic

DNA

EF157669.1 2,00E-030

74

Burkholderiales; Oxalobacteraceae;

Herbaspirillum seropedicae

Bacteria; Proteobacteria;

Betaproteobacteria:Uncultured

beta proteobacterium

(environmental samples); Bacteria;

1778

Xanthomonadales; Xanthomonadac

eae; Ignatzschineria larvae

Bacteria; Proteobacteria;

Gammaproteobacteria;

Hahella chejuensis; Bacteria;

Proteobacteria;

Gammaproteobacteria;

Oceanospirillales;

Halomonadaceae: Carnimonas

nigrificans And Zymobacter palmae

Bacteria; Proteobacteria;

environmental samples:uncultured

proteobacteria

Bacteria; Proteobacteria

Gammaproteobacteria;

environmental samples: uncultured
Proteobacteria;

16S rRNA

Betaproteobacteria;

Burkholderiales;Comamonadaceae;

(environmental samples:

uncultured Comamonadaceae)

Bacteria; uncultured bacterium

(environmental samples); Bacteria;

Proteobacteria;

16S rRNA EU835409.1 2,00E-019 $55 \quad 100$

100

Petaproteobacteria; environmenta

Samples.

Bacteria; Proteobacteria;

Gammaproteobacteria;

Pseudomonadales;Pseudomonadac

eae; Pseudomonas sp.

(environmental samples); Bacteria;

environmental samples

Bacteria; Proteobacteria;
Gammaproteobacter Pseudomonadales Pseudomonadaceae Pseudomonas
ia

Gammaproteobacter

ia

Xanthomonadales Xanthomonadaceae

Ignatzschineria

\section{Ignatzschineri \\ a larvae}

Gacteria; Proteobacteria;

Oceanospirillales; Hahellaceae;

16S rRNA HM980737.1 8,00E-019 54

23S rRNA $\quad$ HM162936.1 3,00E-015

48

100

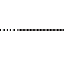

DNA

CP000155.1 5,00E-014

51

96

97

00

Gammaproteobacter Oceanospirillales
ia 
bacteria and gammaproteobacteria;

Bacteria; Proteobacteria;

Betaproteobacteria;

Burkholderiales;Burkholderiaceae;

Burkholderia sp.

Bacteria; environmental samples

Bacteria; environmental samples:

uncultured bacteria

Bacteria; environmental samples:

uncultured bacteria

Bacteria; environmental samples:

Uncultured bacterium

Bacteria; environmental samples:

uncultured bacterium.

Bacteria; environmental samples:

uncultured bacteria

Bacteria; uncultured bacterium

environmental samples.

Bacteria; Uncultured bacteria

environmental samples.

Bacteria; uncultured bacterium

(environmental samples).

Bacteria; environmental samples

\begin{tabular}{|c|c|c|c|c|c|}
\hline $23 \mathrm{~S}$ rRNA & GU924062.1 & $3,00 \mathrm{E}-026$ & 68 & 100 & 100 \\
\hline $16 \mathrm{~S}$ rRNA & AJ874158.1 & $2,00 \mathrm{E}-017$ & 52 & 100 & 100 \\
\hline $16 \mathrm{~S}$ rRNA & GQ480126.1 & $1,00 \mathrm{E}-020$ & 58 & 98 & 100 \\
\hline $16 \mathrm{~S}$ rRNA & GQ480158.1 & $4,00 \mathrm{E}-035$ & 84 & 100 & 100 \\
\hline $23 \mathrm{~S}$ rRNA & DQ313043.1 & $1,00 \mathrm{E}-010$ & 52 & 100 & 92 \\
\hline $16 \mathrm{~S}$ rRNA & GU568902.1 & 2,00E-019 & 55 & 100 & 100 \\
\hline $16 \mathrm{~S}$ rRNA & EU995773.1 & $1,00 \mathrm{E}-028$ & 71 & 100 & 100 \\
\hline $16 \mathrm{~S}$ rRNA & FN777729.1 & $6,00 \mathrm{E}-017$ & 50 & 100 & 100 \\
\hline $16 \mathrm{~S}$ rRNA & HQ343206.1 & $1,00 \mathrm{E}-026$ & 68 & 100 & 100 \\
\hline 235 rRNA & GU926606.1 & $2,00 \mathrm{E}-006$ & 50 & 62 & 100 \\
\hline $18 \mathrm{~S}$ rRNA & AJ236857.1 & $2,00 \mathrm{E}-028$ & 76 & 97 & 98 \\
\hline 18S rRNA & AY651079.1 & $4,00 \mathrm{E}-020$ & 56 & 100 & 100 \\
\hline $28 \mathrm{~S}$ rRNA & EF681936.1 & $7,00 \mathrm{E}-018$ & 53 & 100 & 100 \\
\hline $28 \mathrm{~S}$ rRNA & EF681931.1 & $7,00 \mathrm{E}-023$ & 62 & 100 & 100 \\
\hline $18 \mathrm{~S}$ rRNA & EF577181.1 & $5,00 \mathrm{E}-020$ & 56 & 100 & 100 \\
\hline
\end{tabular}

235

\section{Eukaryota; stramenopiles;}

Chrysophyceae Chromulinales Chromulinaceae Spumella Spumella sp. Chrysophyceae;

Chromulinales; Chromulinaceae;

Spumella; unclassified Spumella sp.

Eukaryota; stramenopiles;

Chrysophyceae; Spumella-like

flagellate; uncultured

Chrysophyceae

Eukaryota; stramenopiles;

$\begin{array}{ccccc}\text { Chrysophyceae } & \text { Chromulinales } & \text { Chromulinaceae } & \text { Spumella } & \text { Spumella sp. } \\ \text { Chrysophyceae } & \text { Chromulinales } & \text { Chromulinaceae } & \text { Spumella } & \text { Spumella sp. }\end{array}$

Chrysophyceae; Chromulinales;

Chromulinaceae; Spumella sp.

Eukaryota; stramenopiles;

\begin{tabular}{|c|c|c|c|c|c|c|c|c|c|c|c|}
\hline Chrysophyceae & Chromulinales & Chromulinaceae & Spumella & Spumella sp. & $\begin{array}{l}\text { Chrysophyceae; Chromulinales; } \\
\text { Chromulinaceae; Spumella sp. }\end{array}$ & $28 \mathrm{~S}$ rRNA & EF681936.1 & 7,00E-018 & 53 & 100 & 100 \\
\hline Chrysophyceae & Chromulinales & Chromulinaceae & Spumella & $\begin{array}{l}\text { Spumella } \\
\text { elongata }\end{array}$ & $\begin{array}{l}\text { Eukaryota; stramenopiles; } \\
\text { Chrysophyceae; Chromulinales; } \\
\text { Chromulinaceae; Spumella } \\
\text { elongata. }\end{array}$ & $28 \mathrm{~S}$ rRNA & EF681931.1 & $7,00 \mathrm{E}-023$ & 62 & 100 & 100 \\
\hline Chrysophyceae & Chromulinales & Chromulinaceae & Spumella & Spumella sp. & $\begin{array}{l}\text { Eukaryota; stramenopiles; } \\
\text { Chrysophyceae; } \\
\text { Chromulinales;Chromulinaceae: } \\
\text { Spumella-like flagellate }\end{array}$ & 18S rRNA & EF577181.1 & $5,00 \mathrm{E}-020$ & 56 & 100 & 100 \\
\hline
\end{tabular}




\begin{tabular}{|c|c|c|c|c|c|c|c|c|c|c|c|}
\hline Chrysophyceae & Chromulinales & Chromulinaceae & Spumella & Spumella sp. & $\begin{array}{l}\text { Eukaryota; stramenopiles; } \\
\text { Chrysophyceae; unclassified } \\
\text { Chrysophyceae: Spumella-like } \\
\text { flagellate }\end{array}$ & 18S rRNA & AY651088.1 & $2,00 \mathrm{E}-019$ & 55 & 100 & 100 \\
\hline Chrysophyceae & Chromulinales & $\begin{array}{l}\text { Chrysolepidomonadac } \\
\text { eae }\end{array}$ & $\begin{array}{l}\text { Chrysolepidom } \\
\text { onas }\end{array}$ & $\begin{array}{l}\text { Chrysolepido } \\
\text { monas } \\
\text { dendrolepidot } \\
\text { a. }\end{array}$ & $\begin{array}{l}\text { Eukaryota; stramenopiles; } \\
\text { Chrysophyceae; Chromulinales; } \\
\text { Chrysolepidomonadaceae; } \\
\text { Chrysolepidomonas } \\
\text { dendrolepidota. }\end{array}$ & $\begin{array}{l}\text { Genomic } \\
\text { DNA }\end{array}$ & AF409121.1 & $6,00 \mathrm{E}-015$ & 50 & 100 & 98 \\
\hline Chrysophyceae & & & & & $\begin{array}{l}\text { Eukaryota; environmental } \\
\text { samples;Eukaryota; stramenopiles; } \\
\text { Chrysophyceae; Hydrurales; } \\
\text { Hydruraceae; } \\
\text { Hydrurus foetidus; Eukaryota; } \\
\text { stramenopiles; Chrysophyceae; } \\
\text { Chromulinales;Chrysolepidomonad } \\
\text { aceae; Chrysolepidomonas } \\
\text { dendrolepidota. }\end{array}$ & $28 \mathrm{~S}$ rRNA & GU928040.1 & 3,00E-021 & 59 & 100 & 100 \\
\hline Chrysophyceae & & & & & $\begin{array}{l}\text { Eukaryota; stramenopiles; } \\
\text { Chrysophyceae; environmental } \\
\text { samples }\end{array}$ & $18 \mathrm{~S}$ rRNA & AB520733.1 & $8,00 \mathrm{E}-057$ & 123 & 100 & 100 \\
\hline Synurophyceae & Synurales & Mallomonadaceae & Mallomonas & $\begin{array}{l}\text { Mallomonas } \\
\text { sp. }\end{array}$ & $\begin{array}{l}\text { Eukaryota; stramenopiles; } \\
\text { Synurophyceae; Synurales; } \\
\text { Mallomonadaceae; Mallomonas sp. }\end{array}$ & $28 \mathrm{~S}$ rRNA & AF409121.1 & $7,00 \mathrm{E}-013$ & 60 & 71 & 100 \\
\hline Synurophyceae & Synurales & Mallomonadaceae & Mallomonas & $\begin{array}{l}\text { Mallomonas } \\
\text { asmundae }\end{array}$ & $\begin{array}{l}\text { Eukaryota; stramenopiles; } \\
\text { Synurophyceae; Synurales; } \\
\text { Mallomonadaceae; Mallomonas } \\
\text { asmundae }\end{array}$ & $\begin{array}{l}\text { ITS1-5.8 } \\
\text { rRNA-ITS2- } \\
\text { 28S rRNA }\end{array}$ & AF409122.1 & $2,00 \mathrm{E}-024$ & 76 & 100 & 94 \\
\hline \multirow[t]{2}{*}{ Chrysophyceae } & Chromulinales & Chromulinaceae & Spumella & Spumella sp. & $\begin{array}{l}\text { Eukaryota; stramenopiles; } \\
\text { Chrysophyceae; Chromulinales; } \\
\text { Chromulinaceae: uncultured } \\
\text { Spumella (environmental samples); } \\
\text { Eukaryota; Uncultured eukaryote } \\
\text { (environmental samples) }\end{array}$ & $18 \mathrm{~S}$ rRNA & GU067799.1 & $2,00 \mathrm{E}-039$ & 91 & 100 & 100 \\
\hline & & & & & $\begin{array}{l}\text { Eukaryota; stramenopiles; } \\
\text { Synurophyceae; } \\
\text { Synurales;Mallomonadaceae: } \\
\text { Mallomonas tonsurata; and } \\
\text { Eukaryota; stramenopiles; } \\
\text { Eustigmatophyceae; } \\
\text { Eustigmatales;Monodopsidaceae; } \\
\text { Nannochloropsis gaditana; and } \\
\text { Eukaryota; stramenopiles; } \\
\text { Chrysophyceae; Chromulinales; } \\
\text { Chrysolepidomonadaceae; } \\
\text { Chrysolepidomonas dendrolepidota }\end{array}$ & $28 \mathrm{~S}$ rRNA & FJ030885.1 & $1,00 \mathrm{E}-018$ & 53 & 100 & 100 \\
\hline
\end{tabular}


Eukaryota; stramenopiles;

Chrysophyceae; environmental

samples:Uncultured chrysophyte;

Eukaryota; stramenopiles;

$\begin{array}{lllll}18 S \text { rRNA } & \text { GU067890.1 } & 2,00 E-012 & 43 & 100\end{array}$

100

Synurophyceae; Ochromonadales;

Ochromonadaceae; environmental

samples:Uncultured Spumella

Eukaryota; stramenopiles;

Synurophyceae; Synurales;

Mallomonadaceae; Mallomonas

sp.; Eukaryota; stramenopiles;

Chrysophyceae; Chromulinales;

$28 \mathrm{~S}$ rRNA

FJ030885.1 1,00E-014

50

Chromulinaceae; Spumella

unclassified Spumella sp.

Eukaryota; stramenopiles;

Synurophyceae; Synurales;

Mallomonadaceae; Mallomonas

asmundae; Eukaryota;

stramenopiles;Chrysophyceae;Chro

Genomic

mulinales;Chrysolepidomonadaceae

DNA

AF409122.1 1,00E-019

59

100

98

; Chrysolepidomonas

dendrolepidota

\begin{tabular}{|c|c|c|c|c|c|c|c|c|c|c|}
\hline Kinetoplastida & Bodonidae & Rhynchomonas & $\begin{array}{l}\text { Rhynchomon } \\
\text { as nasuta }\end{array}$ & $\begin{array}{l}\text { Eukaryota; Euglenozoa; } \\
\text { Kinetoplastida; Bodonidae; } \\
\text { Rhynchomonas nasuta }\end{array}$ & 18S rRNA & DQ465526.1 & $6,00 \mathrm{E}-020$ & 56 & 100 & 100 \\
\hline Kinetoplastida & Bodonidae & Neobodo & $\begin{array}{l}\text { Neobodo } \\
\text { designis }\end{array}$ & $\begin{array}{l}\text { Eukaryota; Euglenozoa; } \\
\text { Kinetoplastida; Bodonidae; } \\
\text { Neobodo designis. }\end{array}$ & 18S rRNA & DQ207585.1 & $9,00 \mathrm{E}-027$ & 69 & 100 & 100 \\
\hline Kinetoplastida & Bodonidae & Neobodo & $\begin{array}{l}\text { Neobodo } \\
\text { designis }\end{array}$ & $\begin{array}{l}\text { Eukaryota; Euglenozoa; } \\
\text { Kinetoplastida; Bodonidae; } \\
\text { Neobodo designis. }\end{array}$ & 18S rRNA & DQ207585.1 & $1,00 \mathrm{E}-020$ & 58 & 100 & 100 \\
\hline Kinetoplastida & Bodonidae & Neobodo & $\begin{array}{l}\text { Neobodo } \\
\text { designis }\end{array}$ & $\begin{array}{l}\text { Eukaryota; Euglenozoa; } \\
\text { Kinetoplastida; Bodonidae; } \\
\text { Neobodo designis }\end{array}$ & 18S rRNA & DQ207585.1 & $7,00 \mathrm{E}-016$ & 51 & 94 & 100 \\
\hline Kinetoplastida & Bodonidae & Neobodo & $\begin{array}{l}\text { Neobodo } \\
\text { designis }\end{array}$ & $\begin{array}{l}\text { Eukaryota; Euglenozoa; } \\
\text { Kinetoplastida; Bodonidae; } \\
\text { Neobodo designis }\end{array}$ & 18S rRNA & DQ207585.1 & $1,00 \mathrm{E}-016$ & 50 & 100 & 100 \\
\hline Kinetoplastida & Bodonidae & Neobodo & $\begin{array}{l}\text { Neobodo } \\
\text { designis }\end{array}$ & $\begin{array}{l}\text { Eukaryota; Euglenozoa; } \\
\text { Kinetoplastida; Bodonidae; } \\
\text { Neobodo designis. }\end{array}$ & $28 \mathrm{~S}$ rRNA & FJ176710.1 & $1,00 \mathrm{E}-016$ & 53 & 100 & 98 \\
\hline Kinetoplastida & Bodonidae & Neobodo & $\begin{array}{l}\text { Neobodo } \\
\text { designis }\end{array}$ & $\begin{array}{l}\text { Eukaryota; Euglenozoa; } \\
\text { Kinetoplastida; Bodonidae; } \\
\text { Neobodo designis }\end{array}$ & 18S rRNA & DQ207585.1 & $5,00 \mathrm{E}-021$ & 58 & 100 & 100 \\
\hline Kinetoplastida & Bodonidae & Neobodo & $\begin{array}{l}\text { Neobodo } \\
\text { designis }\end{array}$ & $\begin{array}{l}\text { Eukaryota; Euglenozoa; } \\
\text { Kinetoplastida; Bodonidae; } \\
\text { Neobodo designis }\end{array}$ & $28 \mathrm{~S}$ rRNA & FJ176710.1 & $5,00 \mathrm{E}-030$ & 86 & 100 & 95 \\
\hline
\end{tabular}




\begin{tabular}{|c|c|c|c|c|c|c|c|c|c|c|}
\hline Kinetoplastida & Bodonidae & Neobodo & $\begin{array}{l}\text { Neobodo } \\
\text { designis }\end{array}$ & $\begin{array}{l}\text { Eukaryota; Euglenozoa; } \\
\text { Kinetoplastida; Bodonidae; } \\
\text { Neobodo designis; }\end{array}$ & $18 \mathrm{~S}$ rRNA & DQ207585.1 & $2,00 \mathrm{E}-018$ & 53 & 100 & 100 \\
\hline Kinetoplastida & Bodonidae & Neobodo & $\begin{array}{l}\text { Neobodo } \\
\text { designis }\end{array}$ & $\begin{array}{l}\text { Eukaryota; Euglenozoa; } \\
\text { Kinetoplastida; Bodonidae; } \\
\text { Neobodo designis }\end{array}$ & 18S rRNA & DQ207585.1 & $8,00 \mathrm{E}-023$ & 61 & 100 & 100 \\
\hline Kinetoplastida & Bodonidae & Neobodo & $\begin{array}{l}\text { Neobodo } \\
\text { designis }\end{array}$ & $\begin{array}{l}\text { Eukaryota; Euglenozoa; } \\
\text { Kinetoplastida; Bodonidae; } \\
\text { Neobodo designis; }\end{array}$ & $18 \mathrm{~S}$ rRNA & DQ207585.1 & $3,00 \mathrm{E}-022$ & 60 & 100 & 100 \\
\hline Kinetoplastida & Bodonidae & & & $\begin{array}{l}\text { Eukaryota; Euglenozoa; } \\
\text { Kinetoplastida; Bodonidae: } \\
\text { Neobodo designis; Bodo sp. }\end{array}$ & 18S rRNA & DQ207585.1 & $2,00 \mathrm{E}-032$ & 79 & 100 & 100 \\
\hline Kinetoplastida & Bodonidae & & & $\begin{array}{l}\text { Eukaryota; Euglenozoa; } \\
\text { Kinetoplastida; Bodonidae: } \\
\text { Bodonidae sp.; Cryptaulax } \\
\text { sp.;Rhynchomonas nasuta }\end{array}$ & 18S rRNA & EU106845.1 & $5,00 \mathrm{E}-015$ & 50 & 100 & 98 \\
\hline Kinetoplastida & Bodonidae & & & $\begin{array}{l}\text { Eukaryota; Euglenozoa; } \\
\text { Kinetoplastida; Bodonidae; } \\
\text { Bodonidae sp.; Eukaryota; } \\
\text { Euglenozoa; Kinetoplastida; } \\
\text { Bodonidae; Rhynchomonas sp.; } \\
\text { Eukaryota; Euglenozoa; } \\
\text { Kinetoplastida; Bodonidae; } \\
\text { Cryptaulax sp. }\end{array}$ & $18 \mathrm{~S}$ rRNA & EU106845.1 & $6,00 \mathrm{E}-019$ & 57 & 100 & 98 \\
\hline Kinetoplastida & Trypanosomatidae & & & $\begin{array}{l}\text { Eukaryota; Euglenozoa; } \\
\text { Kinetoplastida; Trypanosomatidae; } \\
\text { Leishmania sp., Crithidia sp. }\end{array}$ & $\begin{array}{c}\text { 24S alpha } \\
\text { rRNA }\end{array}$ & AM502245.1 & 4,00E-025 & 83 & 90 & 96 \\
\hline Kinetoplastida & Trypanosomatidae & & & $\begin{array}{l}\text { Eukaryota; Euglenozoa; } \\
\text { Kinetoplastida; Trypanosomatidae; } \\
\text { Leishmania major; Trypanosoma sp. }\end{array}$ & $\begin{array}{l}\text { Genomic } \\
\text { DNA }\end{array}$ & СР000079.1 & $1,00 \mathrm{E}-033$ & 83 & 100 & 98 \\
\hline Kinetoplastida & & & & $\begin{array}{l}\text { Eukaryota; Euglenozoa; } \\
\text { Kinetoplastida; Bodonidae; } \\
\text { environmental Samples: uncultured } \\
\text { Bodonid; Eukaryota; Euglenozoa; } \\
\text { Kinetoplastida; Bodonidae; Bodo } \\
\text { sp.; Eukaryota; Euglenozoa; } \\
\text { Kinetoplastida; Trypanosomatidae; } \\
\text { Phytomonas sp. }\end{array}$ & $28 \mathrm{~S}$ rRNA & GQ902915.1 & $9,00 \mathrm{E}-022$ & 60 & 100 & 100 \\
\hline Kinetoplastida & & & & $\begin{array}{l}\text { Eukaryota; environmental samples: } \\
\text { uncultured Eukaryote;Eukaryota; } \\
\text { Euglenozoa; Kinetoplastida; } \\
\text { Bodonidae; Rhynchomonas sp.; } \\
\text { Eukaryota; Euglenozoa; } \\
\text { Kinetoplastida; Trypanosomatidae; } \\
\text { Herpetomonas sp.;Eukaryota; } \\
\text { Euglenozoa; Kinetoplastida; }\end{array}$ & $28 \mathrm{~S}$ rRNA & GU927617.1 & $9,00 \mathrm{E}-019$ & 56 & 100 & 100 \\
\hline
\end{tabular}


Trypanosomatidae; Crithidia sp.

\begin{tabular}{|c|c|c|c|c|c|c|c|c|c|c|c|}
\hline Heterolobosea & Schizopyrenida & Vahlkampfiidae & Naegleria & Naegleria sp. & $\begin{array}{l}\text { Eukaryota; Heterolobosea; } \\
\text { Schizopyrenida; Vahlkampfiidae; } \\
\text { Naegleria lovaniensis and N. fowleri }\end{array}$ & 18S rRNA & U80062.1 & $1,00 \mathrm{E}-019$ & 59 & 94 & 100 \\
\hline Heterolobosea & Schizopyrenida & Vahlkampfiidae & Naegleria & $\begin{array}{l}\text { Naegleria } \\
\text { fowleri }\end{array}$ & $\begin{array}{l}\text { Eukaryota; Heterolobosea; } \\
\text { Schizopyrenida; Vahlkampfiidae; } \\
\text { Naegleria fowleri }\end{array}$ & $18 \mathrm{~S}$ rRNA & U80059.1 & 3,00E-016 & 50 & 100 & 100 \\
\hline Heterolobosea & Schizopyrenida & Vahlkampfiidae & Naegleria & $\begin{array}{l}\text { Naegleria } \\
\text { gruberi }\end{array}$ & $\begin{array}{l}\text { Eukaryota; Heterolobosea; } \\
\text { Schizopyrenida; Vahlkampfiidae; } \\
\text { Naegleria gruberi. }\end{array}$ & $\begin{array}{l}\text { Genomic } \\
\text { DNA }\end{array}$ & AC237584.1 & $8,00 \mathrm{E}-032$ & 90 & 100 & 95 \\
\hline Heterolobosea & Schizopyrenida & Vahlkampfiidae & Naegleria & $\begin{array}{l}\text { Naegleria } \\
\text { gruberi }\end{array}$ & $\begin{array}{l}\text { Eukaryota; Heterolobosea; } \\
\text { Schizopyrenida; Vahlkampfiidae; } \\
\text { Naegleria gruberi. }\end{array}$ & $28 \mathrm{~S}$ rRNA & AB298288.1 & $1,00 \mathrm{E}-019$ & 61 & 100 & 96 \\
\hline Heterolobosea & Schizopyrenida & Vahlkampfiidae & Naegleria & $\begin{array}{l}\text { Naegleria } \\
\text { gruberi }\end{array}$ & $\begin{array}{l}\text { Eukaryota; Heterolobosea; } \\
\text { Schizopyrenida; Vahlkampfiidae; } \\
\text { Naegleria gruberi }\end{array}$ & $\begin{array}{l}\text { extrachrom } \\
\text { osomal } \\
\text { rRNA } \\
\text { plasmid } \\
\text { DNA }\end{array}$ & AB298288.1 & $7,00 \mathrm{E}-023$ & 83 & 100 & 91 \\
\hline Heterolobosea & Schizopyrenida & Vahlkampfiidae & Naegleria & $\begin{array}{l}\text { Naegleria } \\
\text { gruberi }\end{array}$ & $\begin{array}{l}\text { Eukaryota; Heterolobosea; } \\
\text { Schizopyrenida; Vahlkampfiidae; } \\
\text { Naegleria gruberi. }\end{array}$ & $\begin{array}{l}\text { extrachrom } \\
\text { osomal } \\
\text { rRNA } \\
\text { plasmid } \\
\text { DNA }\end{array}$ & AB298288.1 & $9,00 \mathrm{E}-012$ & 64 & 98 & 89 \\
\hline Heterolobosea & Schizopyrenida & Vahlkampfiidae & Naegleria & $\begin{array}{l}\text { Naegleria } \\
\text { gruberi }\end{array}$ & $\begin{array}{l}\text { Eukaryota; Heterolobosea; } \\
\text { Schizopyrenida; Vahlkampfiidae; } \\
\text { Naegleria gruberi }\end{array}$ & $\begin{array}{l}\text { rRNA } \\
\text { plasmid } \\
\text { DNA }\end{array}$ & AB298288.1 & $1,00 \mathrm{E}-021$ & 76 & 97 & 93 \\
\hline Heterolobosea & Schizopyrenida & Vahlkampfiidae & Naegleria & Naegleria sp. & $\begin{array}{l}\text { Eukaryota; environmental } \\
\text { samples;Eukaryota; Heterolobosea; } \\
\text { Schizopyrenida; Vahlkampfiidae; } \\
\text { Naegleria sp. }\end{array}$ & $18 \mathrm{~S}$ rRNA & FN860554.1 & 4,00E-017 & 54 & 100 & 98 \\
\hline Heterolobosea & Schizopyrenida & Vahlkampfiidae & Naegleria & Naegleria sp. & $\begin{array}{l}\text { Eukaryota; Heterolobosea; } \\
\text { Schizopyrenida; Vahlkampfiidae; } \\
\text { Naegleria sp. }\end{array}$ & SSU rRNA & Y10187.1 & $1,00 \mathrm{E}-014$ & 59 & 100 & 94 \\
\hline Heterolobosea & Schizopyrenida & Vahlkampfiidae & Naegleria & $\begin{array}{l}\text { Naegleria } \\
\text { gruberi }\end{array}$ & $\begin{array}{l}\text { Eukaryota; Heterolobosea; } \\
\text { Schizopyrenida; Vahlkampfiidae; } \\
\text { Naegleria gruberi }\end{array}$ & $\begin{array}{l}\text { rRNA } \\
\text { plasmid } \\
\text { DNA }\end{array}$ & AB298288.1 & $4,00 \mathrm{E}-022$ & 71 & 97 & 95 \\
\hline Heterolobosea & Schizopyrenida & Vahlkampfiidae & Naegleria & Naegleria sp. & $\begin{array}{l}\text { Eukaryota; Heterolobosea; } \\
\text { Schizopyrenida; Vahlkampfiidae; } \\
\text { Naegleria sp. }\end{array}$ & 18S rRNA & AY376151.1 & $1,00 \mathrm{E}-017$ & 52 & 100 & 100 \\
\hline Chytridiomycetes & Spizellomycetales & $\begin{array}{l}\text { Spizellomycetales } \\
\text { incertae sedis }\end{array}$ & Rozella & Rozella sp. & $\begin{array}{l}\text { Eukaryota; Fungi; Chytridiomycota; } \\
\text { Chytridiomycetes; } \\
\text { Spizellomycetales; } \\
\text { Spizellomycetales incertae sedis; } \\
\text { Rozella sp. }\end{array}$ & $28 \mathrm{~S}$ rRNA & DQ273766.1 & $9,00 \mathrm{E}-017$ & 72 & 91 & 92 \\
\hline
\end{tabular}


Eukaryota; Fungi; Glomeromycota;

Glomeromycetes Diversiporales Acaulosporaceae Acaulospora $\begin{aligned} & \text { Acaulospora } \\ & \text { scrobiculata }\end{aligned}$

Glomeromycetes;

Diversisporales; Acaulosporaceae;

Acaulospora scrobiculata

Eukaryota; Fungi; environmental

samples: uncultured soil fungus.

$\begin{array}{lllll}\text { 18S rRNA } & \text { FM876791.1 } & 2,00 \mathrm{E}-012 & 83 & 79\end{array}$

87

Eukaryota; Fungi; Dikarya;

Basidiomycota;

Agaricomycotina;Agaricomycetes;

Agaricomycetidae; Agaricales;

Physalacriaceae; Armillaria sp.;

Eukaryota; Fungi; Dikarya;

Ascomycota;

Saccharomycotina;Saccharomycete

s; Saccharomycetales;

Saccharomycetaceae; Pichia sp.

\begin{tabular}{|c|c|c|c|c|c|c|c|c|c|c|c|}
\hline Prasinophyceae & Pyramimonadales & & Pyramimomas & $\begin{array}{l}\text { Pyramimoma } \\
\text { s sp. }\end{array}$ & $\begin{array}{l}\text { Eukaryota; Viridiplantae; } \\
\text { Chlorophyta; Prasinophyceae; } \\
\text { Pyramimonadales; Pyramimonas sp. }\end{array}$ & $28 \mathrm{~S}$ rRNA & EU375499.1 & $5,00 \mathrm{E}-034$ & 91 & 100 & 96 \\
\hline \multirow[t]{8}{*}{ Prasinophyceae } & Pyramimonadales & & Pyramimomas & $\begin{array}{l}\text { Pyramimoma } \\
\text { s sp. }\end{array}$ & $\begin{array}{l}\text { Eukaryota; Viridiplantae; } \\
\text { Chlorophyta; Prasinophyceae; } \\
\text { Pyramimonadales; Pyramimonas sp. }\end{array}$ & $28 \mathrm{~S}$ rRNA & EU375499.1 & $1,00 \mathrm{E}-024$ & 77 & 96 & 95 \\
\hline & Cercomonadida & Cercomonadidae & Cercomonas & $\begin{array}{l}\text { Cercomonas } \\
\text { sp. }\end{array}$ & $\begin{array}{l}\text { Eukaryota; Rhizaria; Cercozoa; } \\
\text { Cercomonadida; Cercomonadidae; } \\
\text { Cercomonas sp. }\end{array}$ & $28 \mathrm{~S}$ rRNA & FJ176707.1 & $9,00 \mathrm{E}-027$ & 69 & 100 & 100 \\
\hline & Cercomonadida & Cercomonadidae & Cercomonas & $\begin{array}{l}\text { Cercomonas } \\
\text { sp. }\end{array}$ & $\begin{array}{l}\text { Eukaryota; Rhizaria; Cercozoa; } \\
\text { Cercomonadida; Cercomonadidae; } \\
\text { Cercomonas sp. }\end{array}$ & $28 \mathrm{~S}$ rRNA & DQ454123.3 & $3,00 \mathrm{E}-024$ & 63 & 100 & 100 \\
\hline & Cercomonadida & Cercomonadidae & Cercomonas & $\begin{array}{l}\text { Cercomonas } \\
\text { sp. }\end{array}$ & $\begin{array}{l}\text { Eukaryota; Rhizaria; Cercozoa; } \\
\text { Cercomonadida; Cercomonadidae; } \\
\text { Cercomonas sp. }\end{array}$ & $28 \mathrm{~S}$ rRNA & FJ176707.1 & $4,00 \mathrm{E}-021$ & 58 & 100 & 100 \\
\hline & Cercomonadida & Cercomonadidae & Cercomonas & $\begin{array}{l}\text { Cercomonas } \\
\text { sp. }\end{array}$ & $\begin{array}{l}\text { Eukaryota; Rhizaria; Cercozoa; } \\
\text { environmental samples: uncultured } \\
\text { Cercozoan; Eukaryota; Rhizaria; } \\
\text { Cercozoa;Cercomonadida; } \\
\text { Cercomonadidae; } \\
\text { Cercomonas sp. }\end{array}$ & $\begin{array}{l}\text { Genomic } \\
\text { DNA }\end{array}$ & FJ353183.1 & $3,00 \mathrm{E}-018$ & 52 & 100 & 100 \\
\hline & & & & & $\begin{array}{l}\text { Eukaryota; Rhizaria; } \\
\text { Cercozoa:uncultured freshwater } \\
\text { cercozoan (environmental samples) }\end{array}$ & $18 \mathrm{~S}$ rRNA & EU567255.1 & $8,00 \mathrm{E}-028$ & 70 & 100 & 100 \\
\hline & & & & & $\begin{array}{l}\text { Eukaryota; environmental } \\
\text { samples:uncultured freshwater } \\
\text { eukaryote }\end{array}$ & 18S rRNA & AY919786.1 & $3,00 \mathrm{E}-033$ & 80 & 100 & 100 \\
\hline & & & & & $\begin{array}{l}\text { Eukaryota; environmental } \\
\text { samples:uncultured freshwater } \\
\text { eukaryote and Uncultured } \\
\text { Amoebozoa }\end{array}$ & 18S rRNA & AY919722.1 & $1,00 \mathrm{E}-034$ & 83 & 100 & 100 \\
\hline
\end{tabular}

$\begin{array}{llllll}\text { 18S rRNA } & \text { EU489955.1 } & 1,00 E-045 & 123 & 100 & 94\end{array}$

\begin{tabular}{|c|c|c|c|c|}
\hline $26 \mathrm{~S}$ rRNA & HM036345.1 & $4,00 \mathrm{E}-015$ & 51 & 100 \\
\hline
\end{tabular}


Cheilostomatida; Flustrina;

Buguloidea; Bugulidae; Bugula

turrita; and Eukaryota; Apusozoa;

Apusomonadidae; Apusomonas sp.

Eukaryota; environmental samples

(uncultured Eukaryote); Eukaryota;

Apusozoa; Apusomonadidae;

Amastigomonas sp.

Eukaryota; Fungi; environmental

samples: Uncultured soil fungus;

Eukaryota; stramenopiles;

26S rRNA EU861712.1 7,00E-013

57

samples

Eukaryota; environmental samples:

uncultured eukaryote and

freshwater eukaryote.

18S rRNA GQ861575.1 4,00E-015

Eukaryota; environmental samples:

Uncultured eukaryote.

\begin{tabular}{llllll}
\hline 18S rRNA & AB521584.1 & $3,00 E-016$ & 50 & 100 & 100 \\
\hline 18S rRNA & AY919722.1 & $9,00 E-017$ & 51 & 100 & 100
\end{tabular}

Eukaryota; environmental samples:

Uncultured freshwater eukaryote.

Eukaryota; Fungi; environmenta

sample: uncultured soil fungus;

Eukaryota; stramenopiles;

Chrysophyceae;

Genomic

DNA

EU489955.1 5,00E-019

55

100

Chromulinales;Chromulinaceae;

Spumella; unclassified Spumella sp.;

Eukaryota; Alveolata; Ciliophora;

environmental samples; Eukaryota;

stramenopiles; Synurophyceae;

Ochromonadales;

Ochromonadaceae; environmental

samples:Uncultured Spumella;

Uncultured chrysophyte

Eukaryota; Nucleariidae;

Micronuclearia sp.; Eukaryota;

Fungi; Dikarya; Ascomycota;

Taphrinomycotina;

Schizosaccharomycetes;

Schizosaccharomycetales;

Schizosaccharomycetaceae;

18S rRNA GU001165.1 1,00E-010

40

Schizosaccharomyces

sp.;Eukaryota; Fungi; Dikarya;

Ascomycota; 
Taphrinomycotina;Taphrinomycete

s; Taphrinales; Taphrinaceae;

Taphrina sp.;Eukaryota; Fungi;

Dikarya; Ascomycota;

Pezizomycotina;Sordariomycetes;

Sordariomycetidae;

Magnaporthales;Magnaporthaceae;

mitosporic Magnaporthaceae;

Phialophora sp.

Eukaryota; environmental samples: uncultured eukaryota;Eukaryota;

Euglenozoa; Kinetoplastida;

$18 S$ rRNA

FN865918.

9,00E-017

51

100

100

Bodonidae; Neobodo sp.

Eukaryota; environmental samples:

uncultured freshwater eukaryote

Eukaryota; environmental samples:

uncultured eukaryote

\begin{tabular}{llllll}
\hline 18S rRNA & AY919786.1 & $5,00 \mathrm{E}-021$ & 57 & 100 & 100 \\
\hline 18S rRNA & FN867270.1 & $3,00 \mathrm{E}-018$ & 73 & 100 & 91 \\
\hline 18S rRNA & FN867270.1 & $4,00 \mathrm{E}-012$ & 56 & 94 & 92 \\
\hline
\end{tabular}

uncultured eukaryote.

Eukaryota; environmental

samples:Uncultured freshwater

$18 \mathrm{~S}$ rRNA

AY919722.1

2,00E-014

46

eukaryote.

Eukaryota; environmental samples:

uncultured eukaryote.

Eukaryota; environmental samples:

uncultured eukaryote.

Eukaryota; environmental samples:

uncultured eukaryote.

Eukaryota; environmental samples:

uncultured eukaryote.

Eukaryota;environmental samples:

uncultured Fungi;Eukaryota;

Rhizaria; Cercozoa; Cercomonadida;

Cercomonadidae;Cercomonas sp.

Eukaryota; uncultured freshwater

eukaryote environmental samples.

Eukaryota; uncultured eukaryote

and freshwater

eukaryote(environmental samples).

Eukaryota; environmental samples.

Eukaryota; Euglenozoa;

1,00E-021

59

N867270.1

4,00E-017

54

18S rRNA

AB273934

7,00E-022

67

18S rRNA

FN862490.1

6,00E-02

56

97

Genomic

DNA

EU516994

6,00E-025

68

18S rRNA

AY919786

(1)

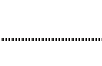

................

18S rRNA $\quad$ FN389650.1 1,00E-020

18S rRNA

$A B 273934$

$1,00 \mathrm{E}-020$

$18 S$ rRNA,

ITS1, 5.8S

FJ712718.1 2,00E-18

2,00E-020

\author{
sp.
}




\begin{tabular}{|c|c|c|c|c|c|c|c|c|c|c|c|}
\hline & & & & & $\begin{array}{l}\text { Eukaryota; Rhizaria; Cercozoa; } \\
\text { Cercomonadida; unclassified } \\
\text { Cercomonadida }\end{array}$ & $28 \mathrm{~S}$ rRNA & $\underline{F J 032646.1}$ & 1,00E-10 & 61 & 100 & 89 \\
\hline Kinetoplastida & & Trypanosomatidae & & & $\begin{array}{l}\text { Eukaryota; Euglenozoa; } \\
\text { Kinetoplastida; } \\
\text { Trypanosomatidae;Leishmania spp.; } \\
\text { Trypanossoma spp.; Blastocrithidia } \\
\text { sp. }\end{array}$ & $\begin{array}{l}24 S \text { alpha } \\
\text { rRNA; } 18 S \\
\text { rRNA; ITS1; } \\
5.8 S \text { rRNA; } \\
\text { ITS2; } 28 S \\
\text { rRNA }\end{array}$ & $\underline{\text { AM502245.1 }}$ & $5,00 E-24$ & 82 & 100 & 92 \\
\hline Chlorophyceae & Chlorococcales & Chlorococcaceae & Chlorococcum & $\begin{array}{l}\text { Chlorococcum } \\
\text { dsp. }\end{array}$ & $\begin{array}{l}\text { Eukaryota; Viridiplantae; } \\
\text { Chlorophyta; Chlorophyceae; } \\
\text { Chlorococcales; Chlorococcaceae; } \\
\text { Chlorococcum }\end{array}$ & $28 \mathrm{~S}$ rRNA & AF183470.1 & $1,00 \mathrm{E}-004$ & 95 & 29 & 100 \\
\hline \multirow[t]{3}{*}{ Prasinophyceae } & Pyramimonadales & & Pyramimomas & $\begin{array}{l}\text { Pyramimoma } \\
\text { ssp. }\end{array}$ & $\begin{array}{l}\text { Eukaryota; Viridiplantae; } \\
\text { Chlorophyta; Prasinophyceae; } \\
\text { Pyramimonadales; Pyramimonas }\end{array}$ & 28S rRNA & EU375499.1 & $3,00 \mathrm{E}-014$ & 51 & 100 & 96 \\
\hline & & & & & $\begin{array}{l}\text { Eukaryota; stramenopiles; } \\
\text { Synurophyceae; Synurales; } \\
\text { Mallomonadaceae; Mallomonas; } \\
\text { Eukaryota; stramenopiles; PX clade; } \\
\text { Phaeophyceae; Laminariales; } \\
\text { Lessoniaceae; Lessonia sp. ; } \\
\text { Eukaryota; stramenopiles; PX clade; } \\
\text { Phaeophyceae; Fucales; } \\
\text { Seirococcaceae; Cystosphaera sp. }\end{array}$ & $28 \mathrm{~S}$ rRNA & FJ030885.1 & $8,00 \mathrm{E}-011$ & 50 & 96 & 93 \\
\hline & & & & & Eukaryota; environmental samples & 18S rRNA & GU474399.1 & $2,00 \mathrm{E}-021$ & 58 & 100 & 100 \\
\hline Proteomyxidea & Reticulosida & Gymnophryidae & Gymnophrys & $\begin{array}{l}\text { Gymnophrys } \\
\text { sp. }\end{array}$ & $\begin{array}{l}\text { Eukaryota; Rhizaria; Cercozoa; } \\
\text { Gymnophrys sp. }\end{array}$ & $28 \mathrm{~S}$ rRNA & FJ973379.1 & $7,00 \mathrm{E}-006$ & 53 & 76 & 100 \\
\hline Heterolobosea & Schizopyrenida & Vahlkampfiidae & Naegleria & $\begin{array}{l}\text { Naegleria } \\
\text { gruberi }\end{array}$ & $\begin{array}{l}\text { Eukaryota; Heterolobosea; } \\
\text { Schizopyrenida; Vahlkampfiidae; } \\
\text { Naegleria gruberi }\end{array}$ & $\begin{array}{l}\text { rDNA } \\
\text { plasmid } \\
\text { DNA }\end{array}$ & AB298288.1 & $2,00 \mathrm{E}-015$ & 53 & 94 & 98 \\
\hline Kinetoplastida & & Bodonidae & Neobodo & $\begin{array}{l}\text { Neobodo } \\
\text { designis }\end{array}$ & $\begin{array}{l}\text { Eukaryota; Euglenozoa; } \\
\text { Kinetoplastida; Bodonidae; } \\
\text { Neobodo designis }\end{array}$ & 18S rRNA & DQ207585.1 & $9,00 \mathrm{E}-020$ & 55 & 100 & 100 \\
\hline
\end{tabular}

